Provided for non-commercial research and education use. Not for reproduction, distribution or commercial use.

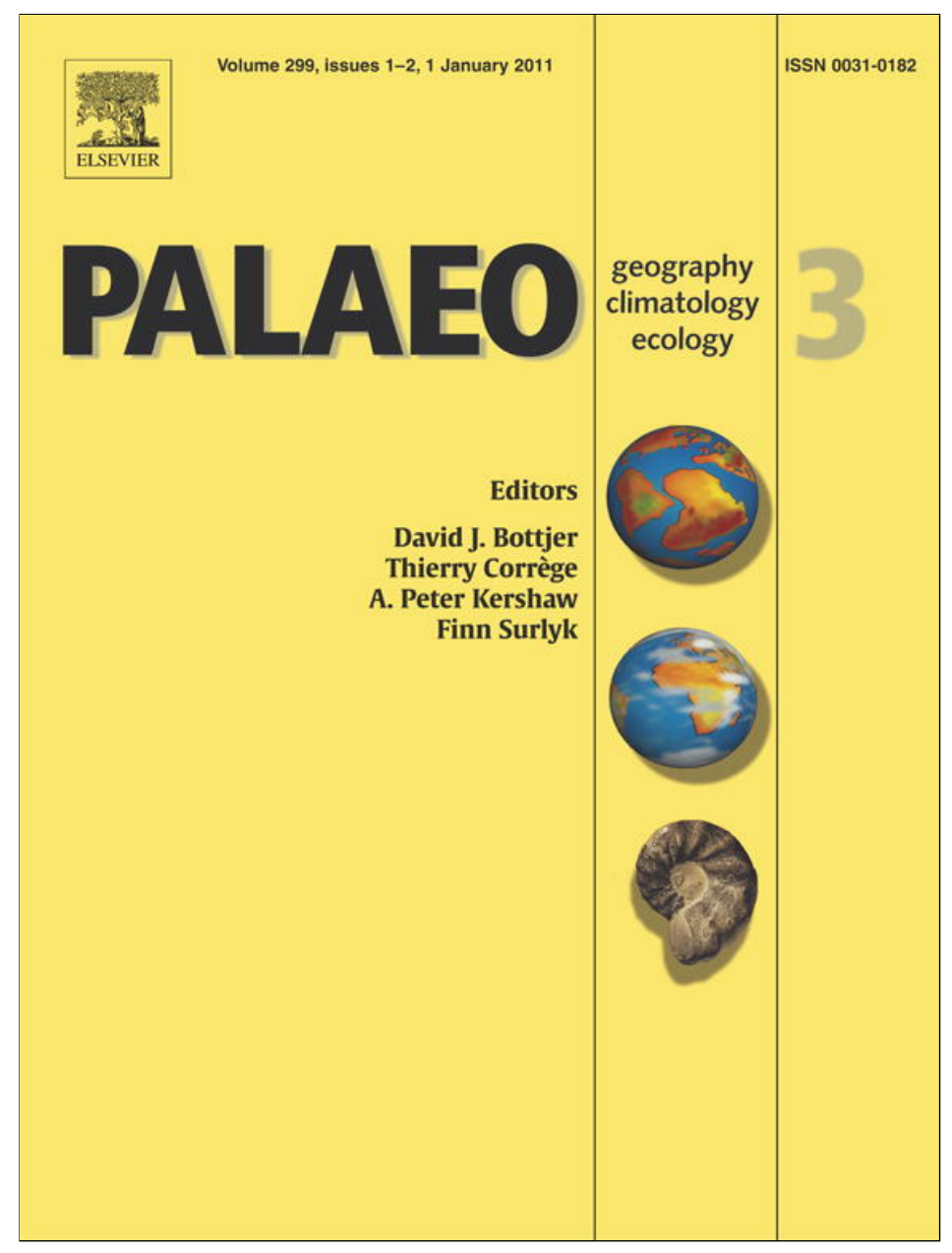

This article appeared in a journal published by Elsevier. The attached copy is furnished to the author for internal non-commercial research and education use, including for instruction at the authors institution and sharing with colleagues.

Other uses, including reproduction and distribution, or selling or licensing copies, or posting to personal, institutional or third party websites are prohibited.

In most cases authors are permitted to post their version of the article (e.g. in Word or Tex form) to their personal website or institutional repository. Authors requiring further information regarding Elsevier's archiving and manuscript policies are encouraged to visit:

http://www.elsevier.com/copyright 


\title{
Late Quaternary paleoenvironmental records from the western Lena Delta, Arctic Siberia
}

\author{
Lutz Schirrmeister $^{\mathrm{a}, *}$, Guido Grosse ${ }^{\mathrm{b}}$, Moritz Schnelle ${ }^{\mathrm{a}}$, Margret Fuchs ${ }^{\mathrm{c}}$, Matthias Krbetschek ${ }^{\mathrm{d}}$, \\ Mathias Ulrich $^{\mathrm{a}}$, Viktor Kunitsky ${ }^{\mathrm{e}}$, Mikhail Grigoriev ${ }^{\mathrm{e}}$, Andrei Andreev ${ }^{\mathrm{f}}$, Frank Kienast ${ }^{\mathrm{g}}$, Hanno Meyer ${ }^{\mathrm{a}}$, \\ Olga Babiy ${ }^{\mathrm{e}}$, Irina Klimova ${ }^{\mathrm{e}}$, Anatoly Bobrov ${ }^{\mathrm{h}}$, Sebastian Wetterich ${ }^{\mathrm{a}}$, Georg Schwamborn ${ }^{\mathrm{a}}$ \\ ${ }^{a}$ Department of Periglacial Research, Alfred Wegener Institute for Polar and Marine Research, Telegrafenberg A43, D-14473 Potsdam, Germany \\ b Geophysical Institute, University of Alaska Fairbanks, 903 Koyukuk Drive, Fairbanks, AK-99775, USA \\ ${ }^{\text {c }}$ TU Bergakademie Freiberg, Institute of Geology, Bernhard-von-Cotta-Strasse 2, D-09596 Freiberg, Germany \\ d Saxon Academy of Science, Section Quaternary Geochronology, Leipziger Str. 23, D-09596 Freiberg, Germany \\ e Permafrost Institute Yakutsk, Russian Academy of Science, Siberian Branch, ul. Merzlotnaya, 36, RUS-677010 Yakutsk, Russia \\ ${ }^{\mathrm{f}}$ Institute of Geology and Mineralogy, University of Cologne, Zuelpicher Str. 49a, D-50674 Cologne, Germany \\ ${ }^{g}$ Senckenberg Research Institute, Quaternary Palaeontology Research Station, Am Jakobskirchhof 4, D-99423 Weimar, Germany \\ ${ }^{\text {h }}$ Moscow State University, Faculty of Soil, Vorobievy Gory, RUS-119899 Moscow, Russia
}

\section{A R T I C L E I N F O}

\section{Article history:}

Received 22 July 2010

Received in revised form 22 October 2010

Accepted 31 October 2010

Available online 4 November 2010

\section{Keywords:}

Periglacial

Permafrost

Cryolithology

Geochronology

Paleoecology

Paleogeography

Laptev Sea shelf

Western Beringia

\begin{abstract}
A B S T R A C T
The three main Lena Delta terraces were formed during different stages of the late Quaternary. While only the first floodplain terrace is connected with active deltaic processes, the second and third terraces, which dominate the western part of the delta, are erosional remnants of arctic paleolandscapes affected by periglacial processes. The landscape dynamics of the second and the third terraces, and their relationship to each other, are of particular importance in any effort to elucidate the late Quaternary paleoenvironment of western Beringia.

Multidisciplinary studies of permafrost deposits on the second terrace were carried out at several sites of the Arga Complex, named after the largest delta island, Arga-Muora-Sise. The frozen sediments predominantly consist of fluvial sands several tens of meters thick, radiocarbon-dated from $>52$ to $16 \mathrm{kyr}$ BP. These sands were deposited under changing fluvial conditions in a dynamic system of shifting river channels, and have been additionally modified by synsedimentary and postsedimentary cryogenesis. Later thermokarst processes affected this late Pleistocene fluvial landscape during the Lateglacial and the Holocene. In addition, eolian activity reworked the fluvial sands on exposed surfaces at least since the Lateglacial, resulting in dune formation in some areas. Contrary to the Arga Complex, the third terrace is mainly composed of polygenetic alluvial and proluvial ice-rich permafrost sequences (Ice Complex deposits) radiocarbon-dated from 50 to 17 kyr BP which cover older fluvial sand units luminescence-dated to about 100-50 kyr BP. Paleoecological records reflect tundra-steppe conditions that varied locally, depending on landscape dynamics, during the Marine Isotope Stage (MIS) 4 and 3 periods, and a persistent change to shrub and arctic tundra during Lateglacial and Holocene periods.

The study results indicate a continuous fluvial sedimentation environment for the Laptev Sea shelf in the region of the second Lena Delta terrace during the late Pleistocene, and confirm the presence of a dynamic channel system of the paleo-Lena River that flowed at the same time as the nearby subaerial Ice Complex deposits were being formed.
\end{abstract}

(c) 2010 Elsevier B.V. All rights reserved.

\section{Introduction}

Arctic river deltas are fragile environmental systems that are situated at the interface between the mainland and the Arctic Ocean. The Lena Delta in North Siberia is the largest Arctic river delta

\footnotetext{
* Corresponding author.

E-mail address: Lutz.Schirrmeister@awi.de (L. Schirrmeister).
}

(Walker, 1998; Fig. 1A). The geology of this region has been studied by Russian researchers since about 1960 (e.g. Galabala, 1987; Grigoriev, 1966, 1993; Gusev, 1961; Ivanov, 1972; Kolpakov, 1983; Kunitsky, 1989; Lungersgauzen, 1961; Saks and Strelkov, 1960). Recently, geological and paleoenvironmental research in the Lena Delta have been continued under Russian-German science collaborations (e.g. Andreev et al., 2004; Krbetschek et al., 2002; Pavlova and Dorozhkina, 2000; Schirrmeister et al., 2003; Schwamborn et al., 2002a,b,c; Wetterich et al., 2008). Schwamborn et al. (2002a) provided a 

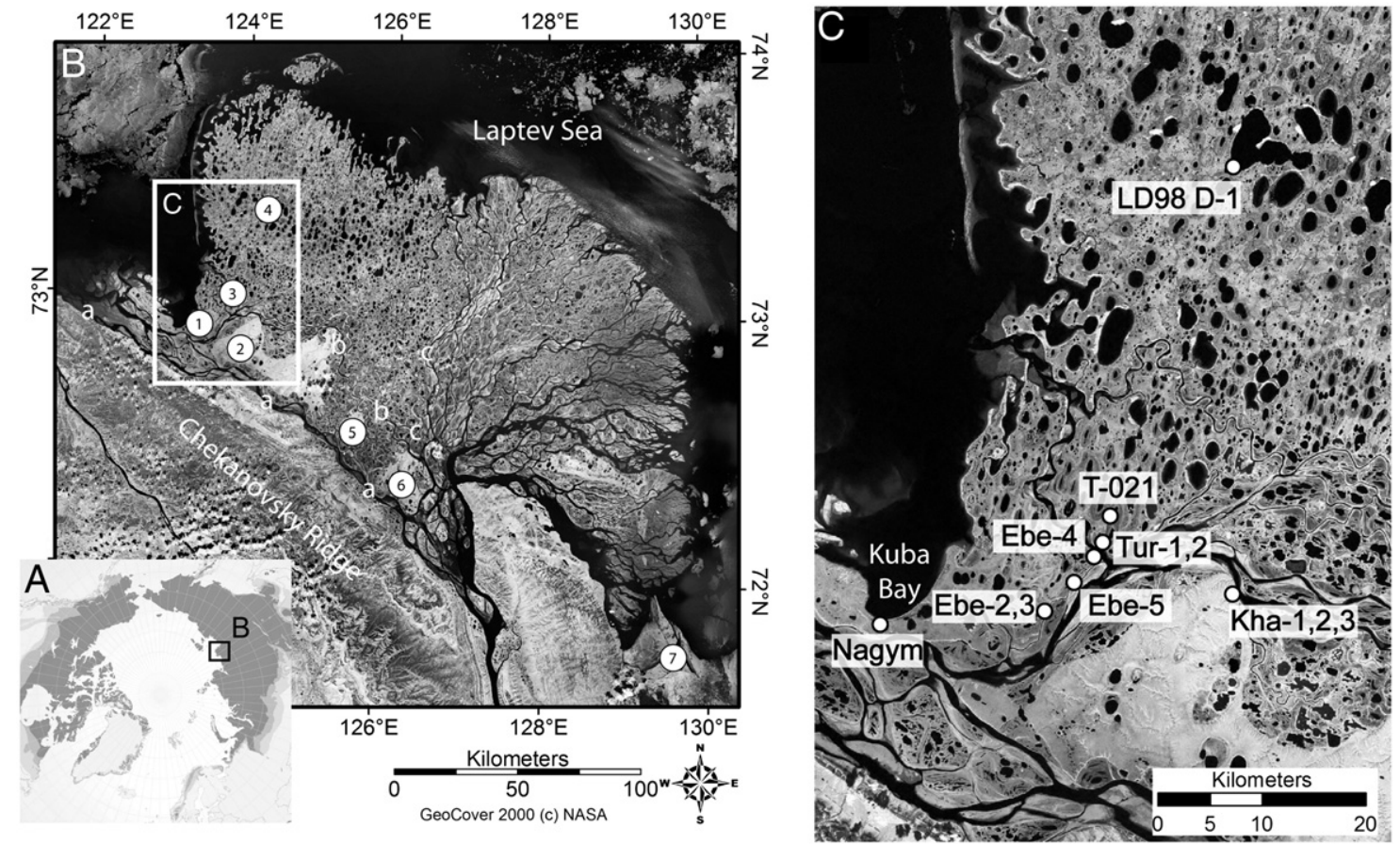

Fig. 1. Study area maps showing (A) the position of the study area on the circum-arctic permafrost map, (B) an overview map with locations mentioned in the text: Islands: 1 - Ebe-BasynSise, 2 - Khardang-Sise, 3 - Turakh-Sise, 4 - Arga-Muora-Sise, 5 - Dzhangilakh-Sise, 6 - Kurungnakh-Sise, 7 - Bykovsky Peninsula; Channels: a - Olenyekskaya, b - Arynskaya, c - Tumatskaya, and (C) the study area in the western Lena Delta with exposure positions (see also SOM-1).

comprehensive picture of the delta architecture, its three main geomorphological terraces, and their genesis. However, one of the still-debated questions concerns the formation of the second terrace in the Lena Delta, the so-called Arga Complex (named after the largest delta island, Arga-Muora-Sise), and its connection to the southern adjoining islands of the third terrace. The Arga Complex was built up of extended and thick sand deposits located in the western part of the delta. The Arga Complex not only differs from the first terrace with its Late Holocene to modern deltaic accumulation, but is also clearly distinguished from the third terrace which is a relic of a late Pleistocene Ice Complex formed on an accumulation plain and predating the delta development. The surface morphology of the second terrace is largely characterized by NNW-SSE-oriented thermokarst depressions often containing lakes (Fig. 1B, C) resembling similar structures on other Arctic plains such as Alaska's North Slope (Hinkel et al., 2005). The dimensions of these thermokarst features cannot be related to current ground ice conditions of the mostly sandy facies of the second terrace but are likely linked to fluvial depressions which originated in a paleo-Lena River bed (Schwamborn et al., 2002a). Still, it was not clear whether the sands of the Arga Complex were facially and stratigraphically correlated with sandy deposits found below the Ice Complex deposits of the third terrace along the Olenyekskaya Channel (Fig. 2). Previous hypotheses describing Arga Complex formation include marine (Ivanov, 1972), lagoonal, limnic-alluvial, alluvial-aeolian (Gusev, 1961; Lungersgauzen, 1961), glaciofluvial (Grosswald, 1998), or fluvio-nival (Galabala, 1987; Kunitsky, 1989) conditions. More recent hypotheses favor fluvial formation by ancient Lena River branches (Grigoriev, 1993; Schwamborn et al., 2002c).

New data on composition and structure of late Quaternary deposits were acquired within the cooperative Russian-German scientific "System Laptev Sea 2000" project from 1998 to 2004 (Grigoriev et al., 2003; Rachold and Grigoriev, 1999, 2000, 2001). To

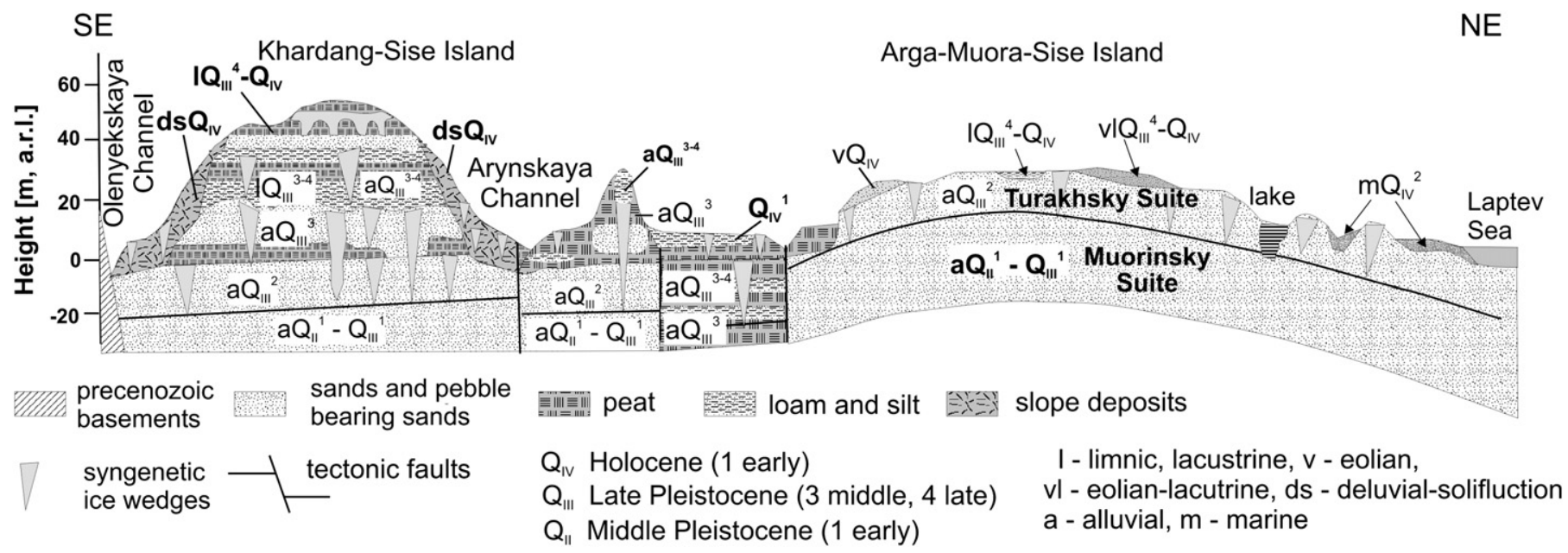

Fig. 2. Schematic cross-section of Quaternary deposits in the western part of the Lena Delta (according to Galabala, 1987). Note: The aQ ${ }_{I I I}^{3-4}$ and aQ ${ }_{\| I I}^{3}$ signatures including large syngenetic ice wedges on Khardang-Sise Island (third Lena Delta terrace) corresponding to the Ice Complex Unit of the third Lena Delta terrace; a.r.l. - above the river level. 
improve understanding of the late Quaternary history of the Lena Delta a field expedition was realized in summer 2005 to focus on periglacial landscape dynamics in the western Lena Delta (Schirrmeister et al., 2007).

The aim of this paper is to synthesize new field observations and analytical results with previous datasets in order to explain the formation of the second terrace (Arga Complex) and its geological relationship to the third terrace, as seen in the context of late Quaternary paleolandscape dynamics in the modern Lena Delta region and broader supraregional paleoenvironmental developments on the Laptev Sea shelf.

\section{Study area}

Three geomorphological terraces occur in the Lena Delta: (1) the first terrace $(0-10 \mathrm{~m}$ above sea level; a.s.l.) is a late Holocene to modern delta floodplain, mainly stretching along the main river channels in the central and eastern parts of the delta; (2) the second terrace (20-30 masl) is of older - presumably late Pleistocene fluvial origin, and is located in the northwestern part of the delta area; (3) the third terrace (30-55 masl) is an erosional remnant of a late Pleistocene accumulation plain north of the Chekanovsky Ridge that covers parts of the southern and southwestern delta areas.

The western Lena Delta is bordered to the east by the Tumatskaya Channel, to the south by the Chekanovsky Ridge, to the west by Kuba Bay, and to the north by the Laptev Sea. Study sites are located on several delta islands, including Ebe-Basyn-Sise, Khardang-Sise, Dzhangylakh-Sise, and Kurungnakh-Sise (Fig. 1B, C). These islands are separated by the Bulukurskaya, Olenyekskaya, and Arynskaya channels and smaller river branches (Fig. 1B). Arga-Muora-Sise Island, the largest island of the western Lena Delta, is located about $20 \mathrm{~km}$ to the north of these studied sites. According to Galabala (1987), the sandy Muorinsky Suite on Arga-Muora-Sise Island is completely covered by Turakhsky Suite sands. These widely-distributed sands were stratigraphically correlated with sand horizons exposed in the lower horizons of the third terrace at the Olenyekskaya Channel (Fig. 2).

The separate and elevated position of the Arga Complex is explained by relative tectonic uplift during the late Quaternary (Are and Reimnitz, 2000; Drachev et al., 1998). Nevertheless, the stratigraphic relationship between the Arga Complex that forms the second terrace and the sandy sequences covered by Ice Complex deposits of the third terrace has not yet been sufficiently explained. Age determinations of sandy deposits at the bluffs of Lake Nikolay on Arga-Muora-Sise show that the sandy deposits at depths of about 1$4 \mathrm{~m}$ below the surface were formed between 14.5 and $10.9 \mathrm{kyr}$ BP (Krbetschek et al., 2002; Schwamborn et al., 2002a), whereas the Lower Sand Unit of the third terrace below the Ice Complex Unit along the Olenyekskaya Channel was luminescence-dated to between 100 and 60 kyr (Schirrmeister et al., 2003; Schwamborn et al., 2002c).

\section{Methods and materials}

\subsection{Cryolithology and sedimentology}

During field work in summer 2005, numerous profiles were excavated in river bank exposures on the second and third Lena Delta terraces. The exposures were described, sketched, and photographed. A total of 240 frozen sediment samples weighing up to $1 \mathrm{~kg}$ each were collected. Ground ice samples (70) were collected separately for stable water isotope analysis. In order to obtain a longer sediment profile from the Arga Complex, an $11.4 \mathrm{~m}$ long core (Tur-2) was drilled in front of an exposed sediment section (Tur-1) at the river bank of the Arynskaya Channel (Fig. 1C). Each core segment (20$30 \mathrm{~cm}$ long) was cleaned, described, photographed, and sampled at $10 \mathrm{~cm}$ intervals. Sample segments $5-10 \mathrm{~cm}$ long were packed in plastic bags. Additionally, core bits were sampled at ca. $1 \mathrm{~m}$ intervals for ice content measurements. Gravimetric ice contents were calculated using the ratio of wet to dry sample weight.

To distinguish various sediment types, basic grain-size parameters were measured with a Laser Particle analyzer (Coulter LS 200). Total carbon (TC), total organic carbon (TOC), and total nitrogen (TN) contents were determined with a Carbon-Nitrogen-Sulfur (CNS) analyzer (Elementar Vario EL III). In addition, the mass-specific magnetic susceptibility (MS) was analyzed using a Bartington MS2 instrument equipped with the MS2B sensor. The values are expressed in SI units $\left(10^{-8} \mathrm{~m}^{3} \mathrm{~kg}^{-1}\right)$. Stable carbon isotope ratios $\left(\delta^{13} \mathrm{C}\right)$ of TOC were measured with a Finnigan DELTA $S$ mass spectrometer. The values are expressed in delta per mil notation $(\delta \%$ ) relative to the Vienna Pee Dee Belemnite (VPDB) Standard and the analyses were accurate to $\pm 0.2 \%$.

\subsection{Geochronology}

Optical stimulated luminescence (OSL) and radiocarbon accelerator mass spectrometry (AMS) methods were used to determine the depositional ages of sands and the age of peat and fossil plant remains.

For OSL analysis, frozen samples were drilled with a batterypowered hand-drilling machine. A modified drill head, opaque plastic cylinders, and opaque plastic bags were used to protect samples from sunlight exposure. Parallel to each OSL sample, sediment was taken for radioisotope analyses using HP-Ge $\gamma$-spectrometry. OSL sample preparation (quartz, $100-160 \mu \mathrm{m}$ ) and age determination were carried out in the Luminescence Laboratory of the Saxon Academy of Science (Inst. of Appl. Physics, TU Freiberg, Germany). To determine the paleodose of each sample, 20-40 aliquots were measured with a Risø DA15 OSL/TL Reader. The measurement procedure followed the single-aliquot regenerative-dose (SAR) protocol of Murray and Wintle (2000). A detailed description of the entire OSL dating procedure, including the statistical data treatments, is given in Schirrmeister et al. (2009). All estimated parameters (paleodose, dose rate, radiation absorption correction, and error analyses) were processed for age calculation with the ADELE software (Kulig, 2005). Previous Infrared Stimulated Optical Luminescence (IRSL) age measurements on potassium feldspar grains were calculated using a multiple aliquot additive (MAAD) protocol (Krbetschek et al., 2002). High errors indicate insufficient bleaching. Therefore, such IRSL ages should be regarded as maximum estimates. We can exclude with confidence the possibility of age underestimation (IRSL-fading) due to the applied dose determination procedure (MAAD, including laboratory fading tests) and the low sediment storage temperatures (permafrost environment).

For radiocarbon dating, small plant fragments like grass roots, leaves, and twigs were separated from the sediment under a stereo microscope and analyzed by AMS at the Leibniz Laboratory for Radiometric Dating and Stable Isotope Research (Kiel, Germany). The Leibniz Laboratory AMS procedures are described in detail by Grootes et al. (2004) and Nadeau et al. (1997, 1998).

\subsection{Mineralogy}

The $63-125 \mu \mathrm{m}$ and $125-250 \mu \mathrm{m}$ subfractions of heavy and light minerals were analyzed. The grains were separated using a sodium metatungstate density solution $\left(2.89 \mathrm{~g} \mathrm{~cm}^{-3}\right)$. Polarized light was used to identify $300-400$ grains of each fraction on microscope slides. The presence of certain mineral types was calculated and expressed as grain percentages.

\subsection{Stable water isotopes of ground ice}

Hydrogen and oxygen isotopes $\left(\delta \mathrm{D}, \delta^{18} \mathrm{O}\right)$ in ground ice were measured with a Finnigan MAT Delta-S mass spectrometer, using 
equilibration techniques. Values are given as per mil difference from Vienna Standard Mean Ocean Water (VSMOW) Standard, with internal $1 \sigma$ errors of less than $0.8 \%$ and $0.1 \%$ for $\delta \mathrm{D}$ and $\delta^{18} \mathrm{O}$, respectively (Meyer et al., 2000). The values are plotted in $\delta^{18} \mathrm{O}-\delta \mathrm{D}$ diagrams in relation to the Global Meteoric Water Line (GMWL) (Craig, 1961). In general, the most negative $\delta^{18} \mathrm{O}$ and $\delta \mathrm{D}$ values reflect the coldest temperatures. Slope and intercept in a $\delta^{18} \mathrm{O}-\delta \mathrm{D}$ diagram indicate the source of ocean water evaporated from different regions, and the possible participation of secondary evaporation processes (Dansgaard, 1964). In addition, the deuterium excess $\left(d=\delta \mathrm{D}-8 \delta^{18} \mathrm{O}\right)$ is an indicator of non-equilibrium fractionation processes (Dansgaard, 1964).

\subsection{Paleoecology}

Pollen samples were prepared with a standard HF acid technique (Berglund and Ralska-Jasiewiczowa, 1986). About 200-300 pollen grains were counted in each sample with $400 \times$ magnification. The pollen percentages are calculated in relation to the total sum of terrestrial pollen. The spore percentages are expressed in relation to the sum of pollen and spores. The relative abundances of reworked Tertiary spores and re-deposited Quaternary pollen are based on the sum of in situ and re-deposited pollen, and the percentages of algae are based on the sum of pollen and algae. The Tilia/TiliaGraph/TGView software (Grimm, 2004) was used for final calculation and graphical presentation of pollen and spore assemblages.

For plant macrofossil studies between 100 and $300 \mathrm{~g}$ of dry minerogenous sediments or between 20 and $80 \mathrm{~g}$ of dried peat were used. The samples were soaked in water and sieved through sieves with $0.25 \mathrm{~mm}$ minimum mesh size. The residue was dried. Plant remains in each sample were identified using a binocular and a reference plant collection (IQW, 2009).

Testate amoebae were separated from $1 \mathrm{~g}$ of sediments with a $500 \mu \mathrm{m}$ sieve and then concentrated with a centrifuge (Bobrov et al., 2004). A drop of the suspension was placed on a slide and fixed with glycerol. Five subsamples were analyzed at $200-400 \times$ magnification under a light microscope.

\section{Results}

\subsection{Cryolithology and sedimentology}

According to cryolithological and sedimentological field and laboratory data, seven sediment units (Units A-G) were classified for the Arga Complex which forms the second terrace of the Lena Delta. Sediments of the third terrace were defined as Lower Sand, Peat, and Ice Complex units (Schirrmeister et al., 2003; Wetterich et al., 2008). Detailed descriptions of various locations are given in this section.

\subsubsection{The second Lena Delta terrace at the Arynskaya Channel}

One drill core (Tur-2) and two exposures (Tur-1, Ebe-4) were studied on both banks of the Arynskaya Channel (Fig. 1C, SOM-1).

The $11.4 \mathrm{~m}$ long Tur-2 core (Fig. 3 ) was extracted next to the Tur-1 exposure, starting one meter above the river level (a.r.l.). The lowermost part of the core at -9.91 to $-8.82 \mathrm{~m}$ below the river level (b.r.l.) was characterized by medium-grained sand with numerous small black patches. A lighter, mica-bearing horizon containing a $2 \mathrm{~mm}$ thick ice vein was found between -8.82 and $-8.27 \mathrm{~m}$ b.r.l. In higher sediments $(-8.27$ to $-4.36 \mathrm{~m}$ b.r.l.), the color changed to spotty orange-brownish due to iron oxide impregnations. In addition, plant detritus interbeds and twig fragments were visible. At $-4.31 \mathrm{~m}$ b.r.l., a second ice vein occurred. At -4.726 to $-0.01 \mathrm{~m}$ b.r.l. the core sequence consisted of grayish, bedded, fine-, medium-, and coarse-grained sand characterized by a massive cryostructure. The next decimeters $(-0.01-0.42 \mathrm{~m}$ b.r.l.) contained a thin vertical ice vein. The uppermost meter consisted of unfrozen modern river sand. The gravimetric ice content varied between 20 and 40 wt.\% with only two ice-rich layers.

The Tur-1 profile (Fig. 3 ) was excavated on the $6 \mathrm{~m}$ high bank of Arynskaya Channel next to the Tur-2 coring location. From 0 to $1.0 \mathrm{~m}$ a.r.l., the profile showed cross-bedded fine- to medium-grained sands, characterized by a massive cryostructure. Further up (1.0-1.5 $\mathrm{m}$ a.r.l.), fine-grained sand with small diagonally-arranged ice veins occurs. The uppermost frozen part (1.5-4.2 $\mathrm{m}$ a.r.l.) features a cryoturbated sandy soil characterized by brownish iron oxide impregnations and humus bands. Its upper boundary corresponds to the permafrost table. The ice veins are comparable to similar structures found on the south bank of Nikolay Lake (exposure D-1) $40 \mathrm{~km}$ to the north (Schwamborn et al., 2002c). An unfrozen peaty layer at 4.2-4.5 m a.r.l. containing a large piece of wood covers the frozen sequence. The following unfrozen horizon (4.5-4.7 $\mathrm{m}$ a.r.l.) is characterized by alternating thin $(2-5 \mathrm{~mm})$ brownish and gray laminae, possibly originating from repeated eolian covering of soil layers.

For sediment characteristics, stratigraphical classification, and correlation, several typical parameters were compared for most of the studied exposures (Fig. 4). Comparable sediment layers were labeled as correlated units (Units A-G). In the combined Tur-2/Tur-1 core and exposure sequence, the lowermost approximately forty centimeters of Unit $A$ at -9.85 to $-9.48 \mathrm{~m}$ b.r.l. consist of well-sorted mediumgrained sand (mean: $200-300 \mu \mathrm{m}$ ) that is almost organic-free (TOC: $<0.1-0.2$ wt.\%), with a high MS $\left(130-580\right.$ SI). Unit $B_{1}$, the section immediately above $(-7.83 \mathrm{~m}$ b.r.l.), is characterized by silty finegrained sand (mean: $120-200 \mu \mathrm{m}$ ) with an upwards gradually-finer mean diameter and a rising TOC content of up to $0.5 \mathrm{wt} . \%$. The MS changes between 20 and 160 SI Unit C, the following $100 \mathrm{~cm}$ thick well-laminated horizon up to $-6.78 \mathrm{~m}$ b.r.l., consists of less- to medium-sorted silty fine sand and sandy silt and contains significantly higher organic carbon (TOC: 0.5-1.6 wt.\%) and lower magnetic mineral content (MS: 20-40 SI). The organic matter content was high enough to measure TN contents and to calculate $\mathrm{C} / \mathrm{N}$ ratios between 17 and 22 and $\delta^{13} \mathrm{C}$ values of -25.3 to $-27.3 \%$. This horizon, radiocarbon-dated to about $52 \mathrm{kyr}$ BP, probably accumulated under the shallow still-water conditions of an oxbow lake. Unit $B_{2}$, the next horizon, is about $270 \mathrm{~cm}$ thick and is granulometrically similar to Unit $\mathrm{B}_{1}$ but contains layers with higher TOC $\left(0.2-1.3\right.$ wt.\%) characterized by $\delta^{13} \mathrm{C}$ values of -25.5 to $-26.7 \%$. With clear changes in several sediment parameters at $-4.38 \mathrm{~m}$ b.r.l., the well-sorted medium-grained sand of Unit D, nearly free of organic carbon and with a lower MS of 10-40 SI, completes the Tur-2 core sequence up to the beach level. Several thin layers with different sediment parameters reflect short-term changes in fluvial accumulation. Unit D continues up to $1.4 \mathrm{~m}$ a.r.l. in the lowermost part of the following Tur-1 exposure sequence. Although grain-size characteristics do not significantly change for the well-sorted medium-grained sand further up, a separate Unit E was classified because of the occurrence of ice veins and higher ice contents as well as cryosol patterns, peat inclusion, and very low MS (5-10 SI). These features probably reflect postsedimentary cryogenic and pedogenic impacts. The $30 \mathrm{~cm}$ thick peaty horizon (Unit F) covering the permafrost table is characterized by a TOC value between 10 and $20 \mathrm{wt} . \%, \mathrm{C} / \mathrm{N}$ ratios of 19 23 , and heavier $\delta^{13} \mathrm{C}$ values of -27.8 to $-29.44 \%$. The entire Tur- 2 /Tur1 sequence is completed by the $60 \mathrm{~cm}$ thick Unit G, composed of wellsorted medium-grained sand (mean: $\sim 270 \mu \mathrm{m}$ ) with low TOC contents (0.1-0.3 wt.\%) and a low MS of 10-20 SI.

A second profile (Ebe-4) was excavated in the opposite $7 \mathrm{~m}$ high bank of the Arynskaya Channel (Figs. 1C and 3). Only the lowest three meters of the approximately $5 \mathrm{~m}$ high profile was frozen. Between 2.0 and $3.0 \mathrm{~m}$ a.r.l., spotty, yellowish-gray-to-brownish sand occurred without any visible sediment or ice structure (ice content 20-24 wt.\%). This horizon was covered by about $10-15 \mathrm{~cm}$ of weakly-bedded finegrained sand with plant detritus. Angular, dark-brown, frozen peat fragments were incorporated into sandy frozen sediments between 3.1 and $4.0 \mathrm{~m}$ a.r.l. More peat inclusions, less angular than those found 
L. Schirrmeister et al. / Palaeogeography, Palaeoclimatology, Palaeoecology 299 (2011) 175-196
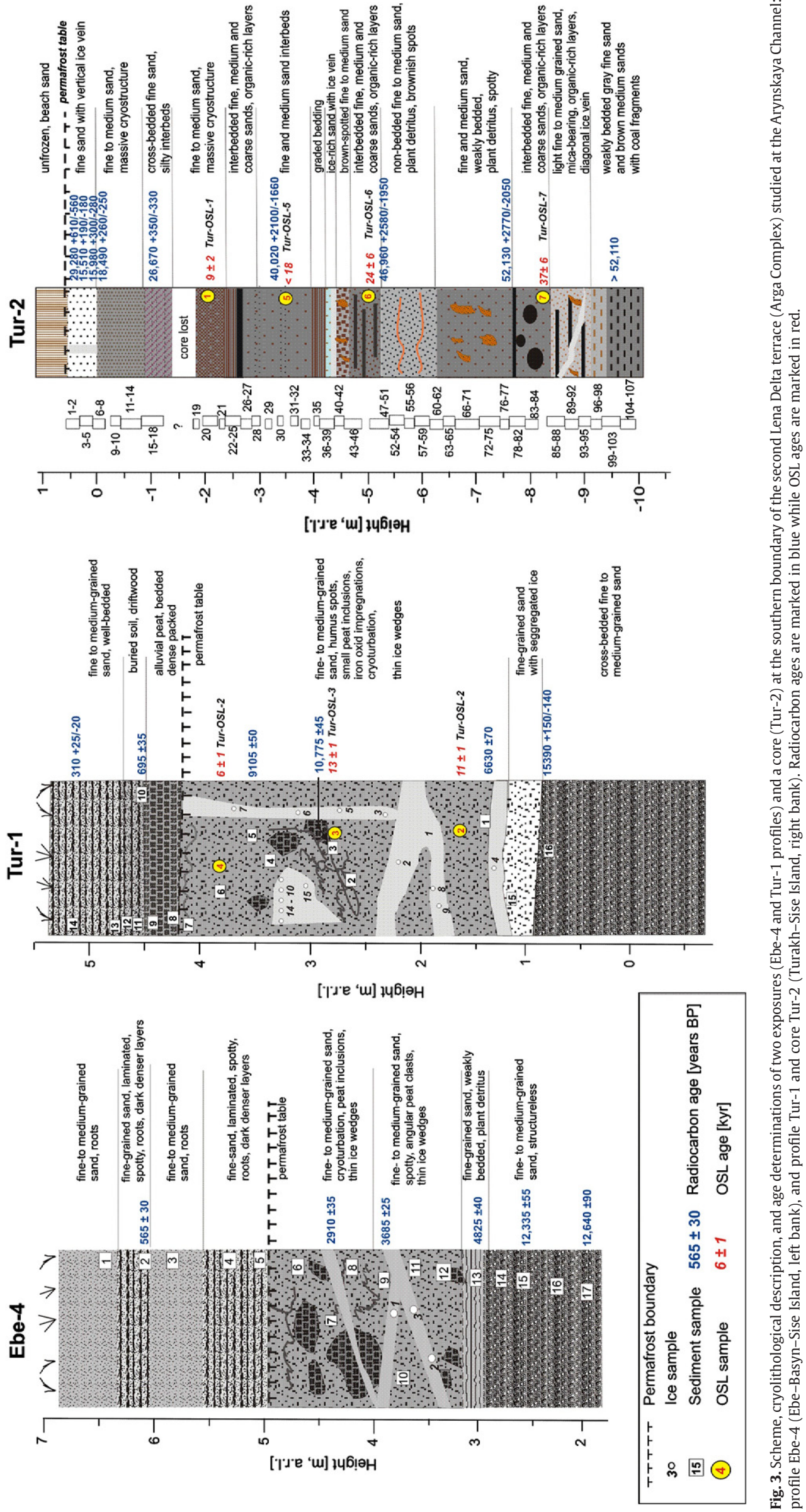


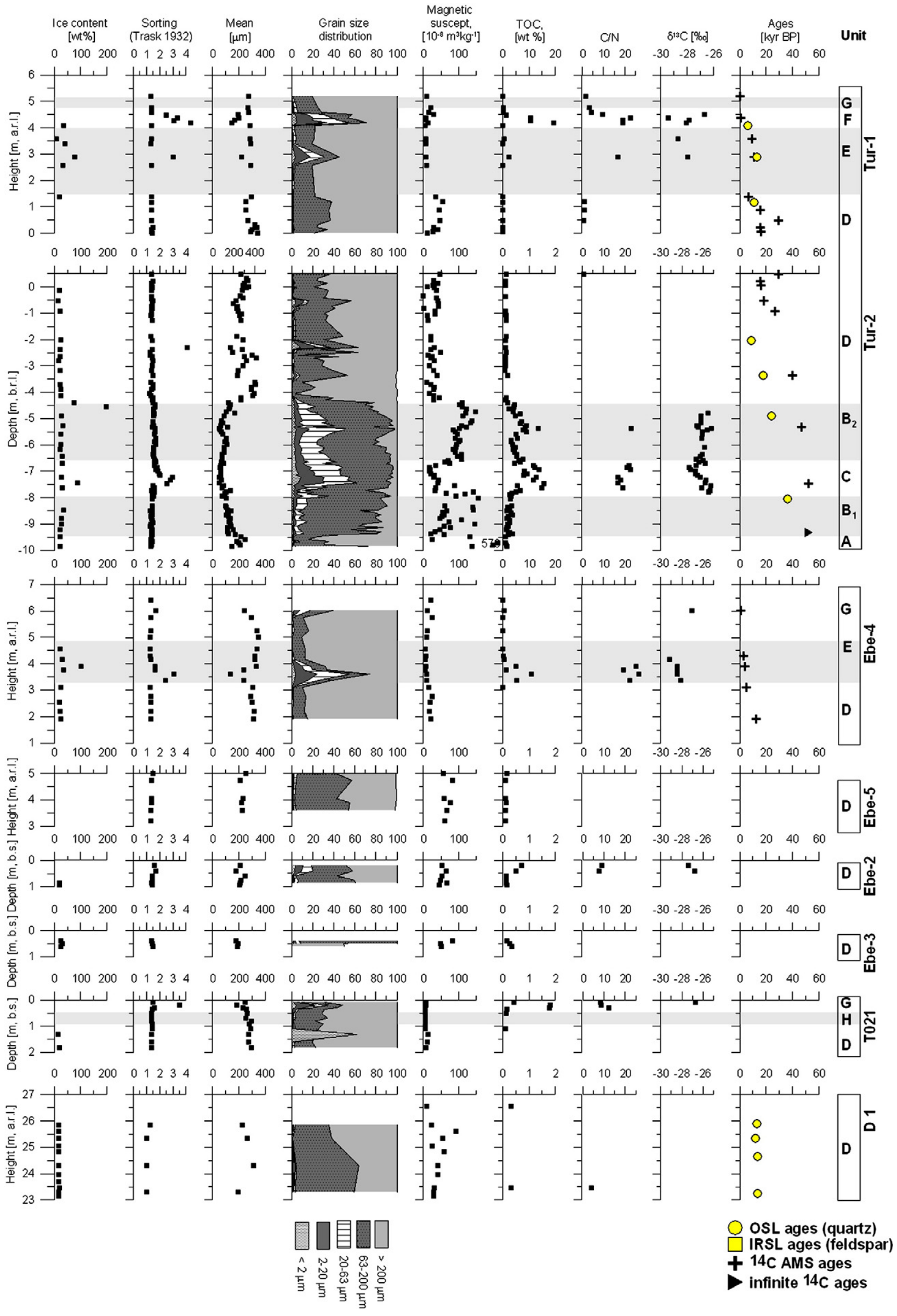


A

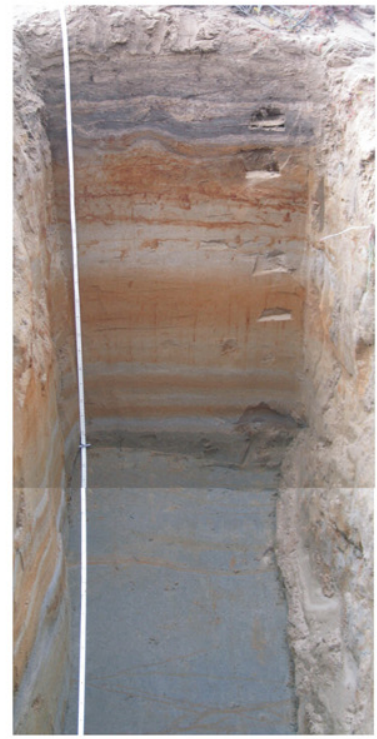

\section{sand with dark-brown iron-oxide schlieres bedded sand}

$\mathbf{T} \mathbf{T} \mathbf{T}$ permafrost table

Iattice-like cracks, orange-brown

grey, fine-grained sand

dune sand
$\mathrm{T}-021$

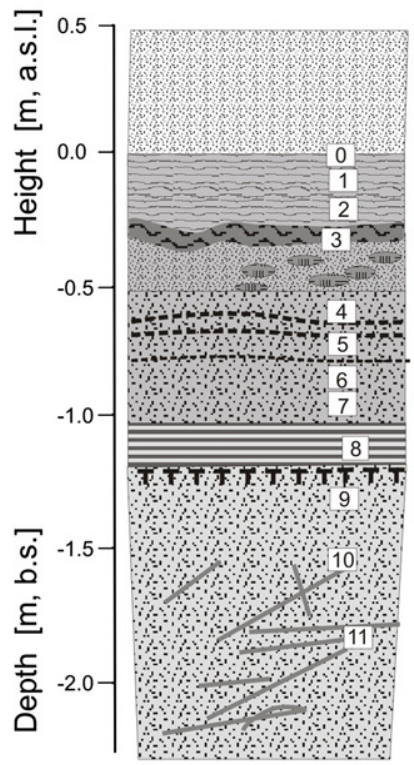

grey and light-yellowish sand, roots

sand layer with orange-brown bands well-bedded sand with organic inclusions

11 sediment sample

$1 \circ$ ice sample

IRSL sample
B LD98-D1

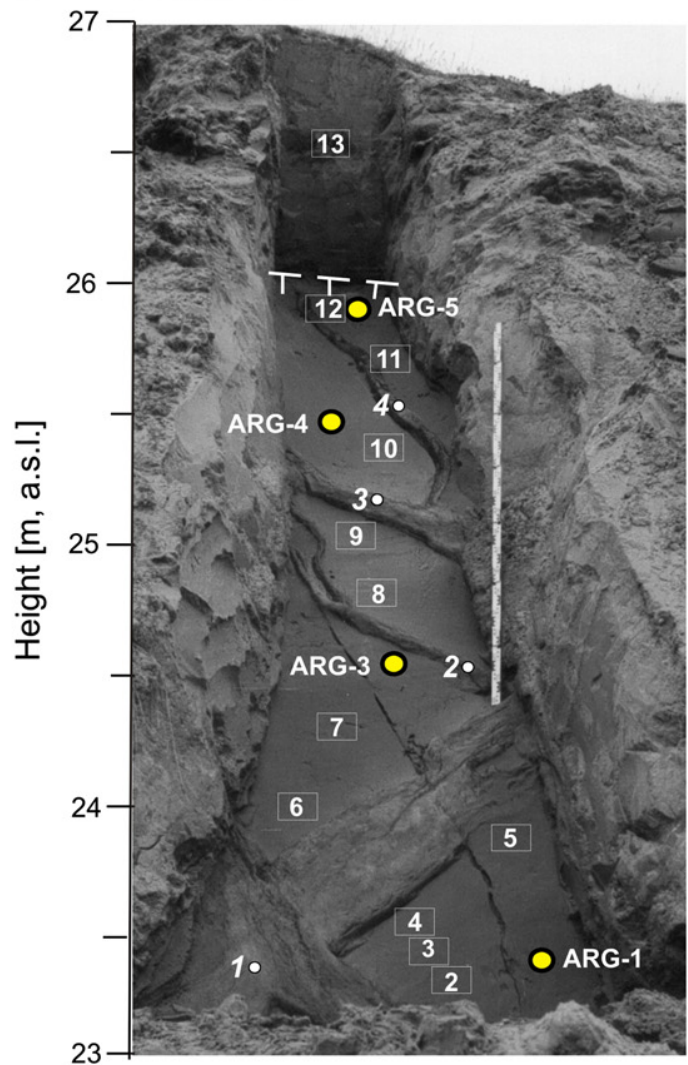

Fig. 5. Additional Arga Complex exposures: (A) Photograph and exposure scheme of T-021 dug in a terrace of a thermokarst lake on Turakh-Sise Island; (B) The LD98-D1 exposure on the southwest bank of Lake Nikolay, Arga-Muora-Sise Island (according to Schwamborn et al., 2002c).

below, were visible between 4.0 and $5.0 \mathrm{~m}$ a.r.l. within frozen, yellowish sand. This peaty-sandy layer featured 2 and $5 \mathrm{~cm}$ wide striped ice-sand veins as well as a sand-filled frost crack. In addition, two horizons showing cryoturbation structures occurred at 4.0 and $4.8 \mathrm{~m}$ a.r.l. Two buried soils about $1 \mathrm{~m}$ thick were observed above the permafrost table. The lower part of these soils was characterized by distinct dark bands.

The Ebe- 4 exposure has a stratigraphical composition similar to that of the Tur-1 exposure (Fig. 4). Well-sorted medium-grained sand (mean: $300 \mu \mathrm{m}$ ) exposed between 1.9 and $3.1 \mathrm{~m}$ a.r.l. is almost free of organic material with an MS of 16-25 SI, corresponding to the sediment parameters of Unit $\mathrm{D}$ ( see earlier discussion). The quite ice-rich horizon up to the permafrost table at $5 \mathrm{~m}$ a.r.l. is characterized by a high TOC of 5-11 wt.\%, C/N of 20-27, and $\delta^{13} \mathrm{C}$ values of -28.1 to $-28.5 \%$. Because of the sediment characteristics and the occurrence of ice veins and cryoturbance patterns, this horizon is defined as Unit E. The topmost layer of the Ebe-4 exposure was classified as cover Unit G. It is about two meters thick and consists of well-sorted medium-grained sand (mean: 240-350 $\mu \mathrm{m}$ ) with low organic content (TOC: $<0.1-0.6 \mathrm{wt} . \%$ ) and an MS of 9-26 SI.

4.1.2. The second Lena Delta terrace on Turakh-Sise and Arga-MuoraSise islands

The T-021 exposure was excavated on Turakh-Sise Island at about 3 masl into a terrace level, often surrounding the oriented thermo- karst lakes on the Arga Complex (Figs. 1B and 5A). The permafrost boundary was found $1.25 \mathrm{~m}$ below the surface (b.s.). The lowermost gray, frozen sands (ice content 15-20 wt.\%) are penetrated by orangebrown-colored cracks with orientations similar to those of the ice veins described in the previous exposures. Above the permafrost boundary, alternate-bedded, gray-to-orange sand is covered by $25 \mathrm{~cm}$ of sand exhibiting dark-brown iron-oxide impregnation. At 0.50$0.75 \mathrm{~m}$ b.s. a layer with horizontal, orange-brown bands was visible. Between 0.25 and $0.5 \mathrm{~m}$ b.s., the well-bedded sand contains more organic matter and was spotty-orange to gray in color. The uppermost part of the profile consists of gray and light-yellowish sand with roots. Finally, a layer of dune sand about $0.5 \mathrm{~m}$ thick had accumulated at the surface.

The lowest part of the T-021 exposure (Fig. 1C) between 1.1 and $2.0 \mathrm{~m}$ b.s, is composed of well-sorted fine- to medium-grained sand (mean: 275-300 $\mu \mathrm{m}$ ) with low MS (5-13 SI) and low TOC values $(<0.1-$ 0.17 wt.\%). Together with the observed crack pattern (Fig. 5A) this horizon is similar to Unit $\mathrm{E}$, which is exposed in all other profiles of the Arga Complex area. According to sediment parameters, the next unfrozen horizon between 0.35 and $1.0 \mathrm{~m}$ b.s. is similar to Unit $\mathrm{D}$, but because of the bedding structure and location near the lake shore it is regarded as a separate lacustrine sediment, Unit $\mathrm{H}$. The uppermost $30 \mathrm{~cm}$ thick layer with TOC values between 0.4 and $1.8 \mathrm{wt} . \%, \mathrm{C} / \mathrm{N}$ values of $8.4-12.3$, and a $\delta^{13} \mathrm{C}$ value of $-26.7 \%$ is labeled as cover Unit G. 
Table 1

Radiocarbon AMS dating results from the core Tur-2 sequence, and the Tur-1, Ebe-4, and Kha-2 exposures. Calibration was accomplished using CALIB rev 4.3 software (Stuiver et al., 1998).

\begin{tabular}{|c|c|c|c|c|c|c|}
\hline Lab. no. & Sample & Description & $\begin{array}{l}\text { Depth } \\
\text { (m b.s.) }\end{array}$ & $\begin{array}{l}\text { Height } \\
\text { (masl) }\end{array}$ & $\begin{array}{l}\text { Radiocarbon ages } \\
\text { (years BP) }\end{array}$ & $\begin{array}{l}\text { Calibrated ages } \\
\text { (cal. BP), } \sigma 95 \%\end{array}$ \\
\hline KIA29866 & Tur-1-14 & Plant remains & 0.2 & 5.18 & $310+25 /-20$ & $443-350$ \\
\hline KIA29865 & Tur-1-10 & Driftwood & 1.0 & 4.38 & $695 \pm 35$ & $686-629$ \\
\hline KIA31040 & Tur-1-1 & Plant remains & 4 & 1.38 & $6630 \pm 70$ & $7624-7940$ \\
\hline KIA31039 & Tur-1-5 & Plant remains & 1.9 & 3.58 & $9105 \pm 50$ & $10,401-10,186$ \\
\hline KIA29249 & Tur-1-3 & Peat inclusion & 2.5 & 2.88 & $10,775 \pm 45$ & $13,001-12,771$ \\
\hline KIA31041 & Tur-1-S-15/S-16 & Plant remains & 4.35 & 1.03 & $15,390+150 /-140$ & $19,052-17,840$ \\
\hline KIA31042 & Tur-2-1 & Plant remains & 1.04 & 0.477 & $29,280 \pm 610$ & \\
\hline KIA31043 & Tur-2-3 & Plant remains & 1.29 & 0.22 & $15,510 \pm 190$ & $19,238-17,875$ \\
\hline KIA31044 & Tur-2-4/2-5 & Plant remains & 1.4 & 0.1 & $15,980+300 /-280$ & $19,949-18,216$ \\
\hline KIA31045 & Tur-2-7 to $2-11$ & Plant remains & 1.53 to 2.10 & -0.03 to -0.52 & $18,490+260 /-250$ & $22,845-21,093$ \\
\hline KIA29250 & Tur-2-15 & Plant remains & 2.34 & -0.91 & $26,670+350 /-330$ & \\
\hline KIA29251 & Tur-2-30 & Plant remains & 4.88 & -3.36 & $40,020+2100 /-1660$ & \\
\hline KIA29252 & Tur-2-50 & Plant remains & 6.84 & -5.32 & $46,960+2580 /-1950$ & \\
\hline KIA29867 & Tur-2-76 & Twigs & 8.97 & -7.45 & $52,130+2770 /-2050$ & \\
\hline KIA29253 & Tur-2-99 & Plant remains & 10.82 & -9.30 & $>52,110$ & \\
\hline KIA29862 & Ebe-4-2 & Plant remains & 0.75 & 6.01 & $565 \pm 30$ & $642-585$ \\
\hline KIA31036 & Ebe-4-7 & Peat moss & 2.45 & 4.31 & $2910 \pm 35$ & $3084-2951$ \\
\hline KIA29863 & Ebe-4-9 & Peat & 2.85 & 3.91 & $3685 \pm 25$ & $4092-3924$ \\
\hline KIA31037 & Ebe-4-13 & Peat moss & 3.65 & 3.11 & $4825 \pm 40$ & 5556-5471 \\
\hline KIA29864 & Ebe-4-15 & Plant remains & 4.2 & 2.56 & $12,335 \pm 55$ & $15,431-14,534$ \\
\hline KIA31038 & Ebe-4-17 & Peat moss & 4.85 & 1.91 & $12,640 \pm 90$ & $15,626-14,293$ \\
\hline KIA31035 & Kha-2-32 & Plant remains & & 16.5 & $20,100 \pm 100$ & \\
\hline KIA31064 & Kha-2-28 & Twigs & & 14.5 & $24,890 \pm 160$ & \\
\hline KIA31034 & Kha-2-24 & Peat inclusion & & 10.1 & $28,050 \pm 190$ & \\
\hline KIA31033 & Kha-2-18 & Plant remains & & 8.6 & $29,770 \pm 250$ & \\
\hline KIA31032 & Kha-2-13 & Peat & & 6.6 & $>50,020$ & \\
\hline KIA31031 & Kha-2-7 & Peat moss & & 5.0 & $>52,090$ & \\
\hline KIA31030 & Kha-2-3 & Peat inclusion & & 4.2 & $>49,030$ & \\
\hline KIA31029 & Kha-2-1 & Peat inclusion & & 3.1 & $>43,550$ & \\
\hline
\end{tabular}

An exposure (LD98-D1) located in the center of Arga-MuoraSise Island on Nikolay Lake's southern bank (23-27 masl) studied by Schwamborn et al. (1999, 2002c) (Fig. 1B, C) indicates sediments with horizontal lamination on an $\mathrm{mm}$ - to $\mathrm{cm}$-scale. The sediments contain 15-20 wt.\% ice and a system of already-described connected ice veins (Fig. 5B). The deposits consists of well-sorted fine and medium-grained sand (mean grain size: $200-300 \mu \mathrm{m}$ ) almost free of organic carbon (TOC: $0-0.3$ wt.\%) and with an MS of 10-60 SI. These parameters correspond very well with the characteristics of Unit D.

\subsubsection{The second Lena Delta terrace in transition to the third Lena Delta} terrace on Ebe-Basyn-Sise Island

The northern area of Ebe-Basyn-Sise Island, where the lateral contact between Arga Complex and Ice Complex was assumed, was studied in three profiles (Ebe-2, Ebe-3, and Ebe-5) (Fig. 1C, Table 1).

The Ebe-2 exposure (SOM-2 A) was excavated at about $18 \mathrm{~m}$ a.r.l on the western slope of a hill located in the transition area between the second and the third terraces. The lower frozen part of the $1 \mathrm{~m}$ deep profile featured grayish fine-grained sand (ice content ca. $19 \mathrm{wt} . \%$ ). Therein, a $5 \mathrm{~cm}$ thick horizontal ice vein composed of horizontal striped and vertical needle-like structures was observed. Above the permafrost table a $15 \mathrm{~cm}$ thick well-bedded gray sand and a brownish-gray, nonbedded, silty-fine sand containing vertical grass roots were exposed. Further up, a $25 \mathrm{~cm}$ thick rooted and cryoturbated brownish soil horizon was covered by $5 \mathrm{~cm}$ thick gray, dry fine sand, probably of eolian origin.

The $0.6 \mathrm{~m}$ deep Ebe- 3 profile was excavated at about 16 masl in the same area into a northern hill slope. The small pit (SOM-2 A) exposed frozen grayish-brown fine sand with concentric rings of iron oxide impregnations between 0.3 and $0.6 \mathrm{~m}$ depth (ice content $25-30 \mathrm{wt} . \%$ ). Above the permafrost table, grayish fine sand containing small brownish bands and a cryoturbated brown horizon formed the modern soil layer.

Two subprofiles of the Ebe-5 exposure were excavated into the $6 \mathrm{~m}$ high cliff on the left bank of a small channel flowing parallel to the
Utyan-Uyesya Channel (Fig. 1C), which exposed unfrozen sands and frozen sands with diagonal ice veins (SOM-2 B). Undulate-bedded, fine- to medium-grained, gray and frozen sand was exposed $3 \mathrm{~m}$ a.r.l. Just below the permafrost table a $5 \mathrm{~cm}$ thin ice vein was connected to a $0.3 \mathrm{~m}$ wide diagonal ice vein. The thin ice vein was horizontally striped and contained many gas bubbles. Well-bedded, fine- to medium-grained sand occurred above the permafrost table, and was sampled up to $5 \mathrm{~m}$ a.r.l.

The Ebe-2, Ebe-3, and Ebe-5 exposures located several kilometers to the southwest on Ebe-Basyn-Sise Island (Fig. 1C) are composed of well-sorted fine- to medium-grained sand with similar MS values of 50-80 SI and low TOC values of 0.17-0.35 wt.\%. Only the cryosol horizon of Ebe- 2 contains more organic carbon ( 0.5 to 0.7 wt.\%). These characteristics correspond widely to Unit D (Fig. 4).

4.1.4. The third Lena Delta terrace on Khardang-Sise, Ebe-Basyn-Sise, and Kurungnakh-Sise islands

An exposure on the northwest bluff of Khardang-Sise Island (Fig. 1B, SOM-1) was studied in order to understand the stratigraphical relationship between the second terrace sands of the Arga Complex and the Lower Sand Unit of the third terrace. The $20 \mathrm{~m}$ high bluff was excavated in three sections (Kha-1, -2 , and -3 ). Several subprofiles (Kha-2 A-E) were exposed in thermokarst mounds. The identified permafrost deposits consist of four different units (Fig. 6). The lower part is the Lower Sand Unit that extends from the beach to $5 \mathrm{~m}$ a.r.l., followed by a 1-2 $\mathrm{m}$ thick peat horizon, a peaty-sandy transition zone (Peat Unit) about $1.5 \mathrm{~m}$ thick, and the Ice Complex Unit up to $12 \mathrm{~m}$ thick on top. Large ice wedges typical of Ice Complex exposures could not be excavated. However, thermokarst mounds indicate their presence.

The lower part of the cliff (Fig. 6, Kha-1) is mostly composed of horizontally-laminated and cross-bedded medium- to fine-grained frozen sands with silty interbeds (Lower Sand Unit). Only the lowermost $2.5 \mathrm{~m}$ could be excavated and sampled. The ice content was 24-32 wt.\%. In addition, cracks filled with small ice crystals occurred within the frozen sandy deposits. 


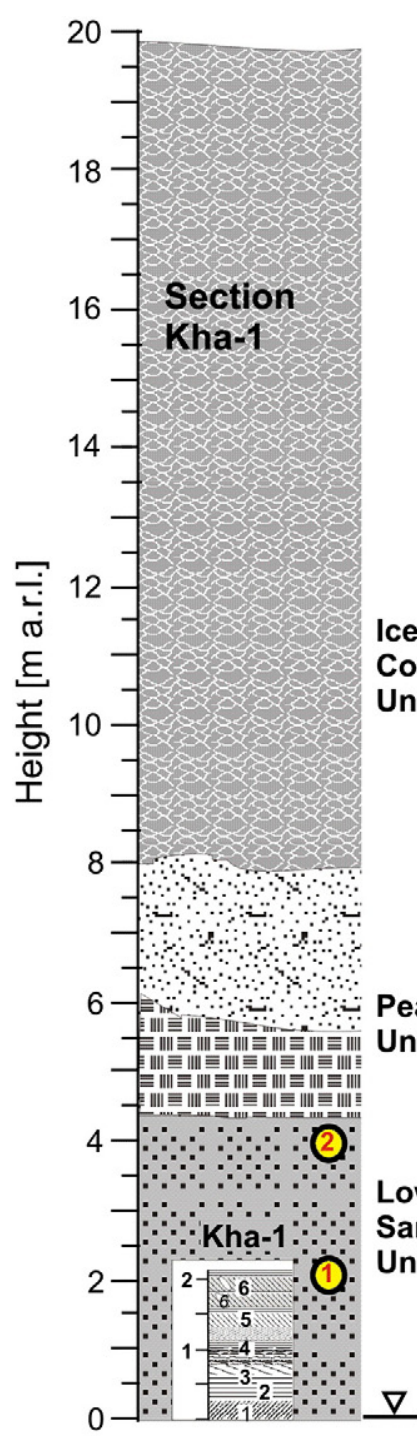

1 sediment sample

\section{(1) OSL sample}

${ }_{4-7}^{8}$ ice wedge sample

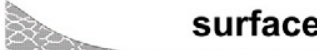

Kha-2 E

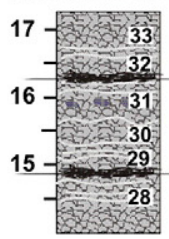

ce

Unit

\section{Peat \\ Unit}

Lowe

Sand

$\nabla \begin{aligned} & \text { river } \\ & \text { level }\end{aligned}$

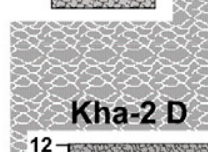

Kha-2 D

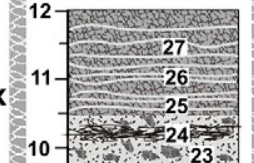

10 - 24

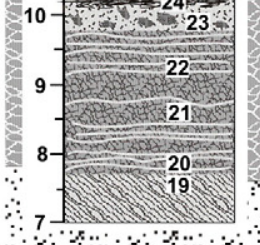

Kha-2C

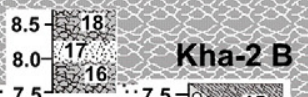

${ }_{7.5}^{8.0} 16.3 .5$ Kha-2 B

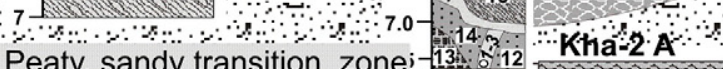
sition zone;-13: 12 主 iㅔ

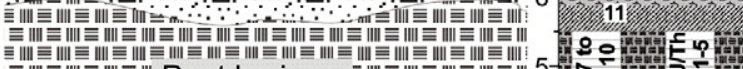

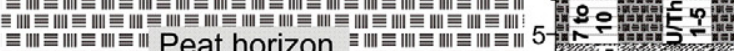

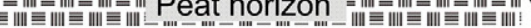

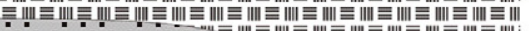

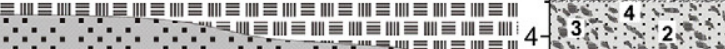

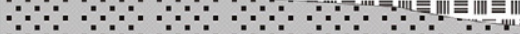

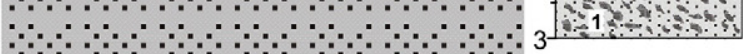

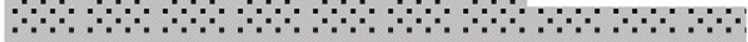

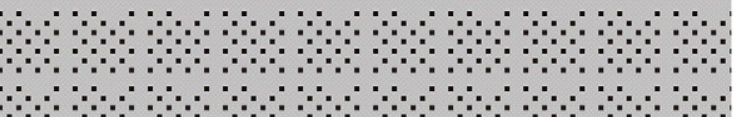

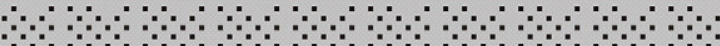

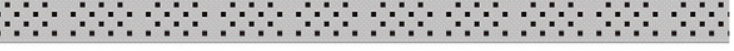

ice band
silty fine sand with
reticulated seggegation ice
palaeosol

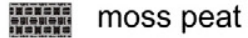

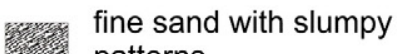
patterns

peat fragments in fine sand

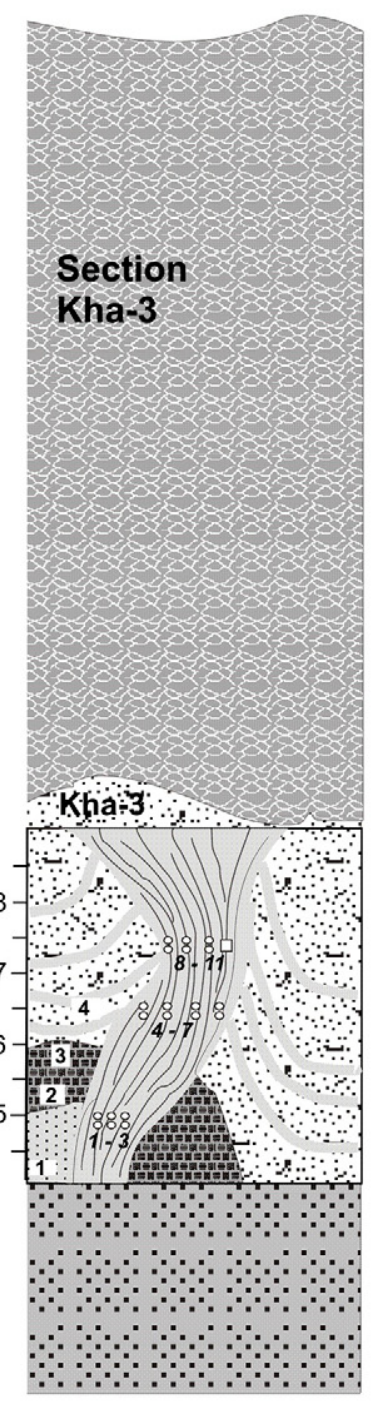

cross-bedded sand

horizontal lamination

Fig. 6. Scheme and cryolithological description of one exposure sequence (Kha profiles) of the third Lena Delta terrace on Khardang-Sise Island.

A Peat Unit extends between 5 and $7 \mathrm{~m}$ a.r.l. along the studied cliff section (Fig. 6, Kha-2 A). The lowermost layer consists of peat fragments in fine-laminated, grayish-green, fine-grained sand (ice content $25-55 \mathrm{wt} . \%)$. A thin layer above is sandier and shows slumping structures. Further up, a $0.5 \mathrm{~m}$ layer of frozen moss peat (ice content $105 \mathrm{wt} . \%$ ) reflects autochthonous accumulation. The peat horizon is overlain by grayish-brown cross-bedded sand. Even further up, strongly-disturbed sediment structures probably indicate refrozen modern slump material; therefore, this material was not sampled.

Between 6.5 and $7.5 \mathrm{~m}$ a.r.l. (Fig. 6, Kha-2 B), lattice-like intersecting ice veins (up to $15 \mathrm{~cm}$ wide) were exposed consisting of parallel and alternating ice and sand bands. A larger peat inclusion was covered by grayish fine sand containing the ice veins. Above the ice wedges, yellowish-gray silty fine sand showed sloping parallel structures. The lower part of the Ice Complex Unit was exposed between 7.5 and $8.5 \mathrm{~m}$ a.r.l. (Fig. 6, Kha-2C). This subprofile consisted of two layers featuring ice-rich dark grayish-brown silty fine sand with banded cryostructures (ice content 38-44 wt.\%) alternating with grayish-brown sand with ripple-bedding (ice content $26 \mathrm{wt} . \%$ ). The layers contained weakly-developed cryoturbated paleosol horizons. Similar deposits were observed up to $12 \mathrm{~m}$ a.r.l. (Fig. 6, Kha-2 D). Icerich grayish sands (0.1-0.3 m thick) containing twig fragments, ice bands, and lens-like broken cryostructures alternated with light-gray to brownish sand layers (about $0.2 \mathrm{~m}$ thick). Between 14.5 and $17 \mathrm{~m}$ a.r.l., the uppermost Kha-2 E subprofile consists of several alternating layers of ice-rich, ice-banded silty fine sand. Several lens-like reticulated cryostructures and ice-poor paleosol horizons with peat inclusions can also be observed. The ice content ranged between 50 and 115 wt.\%.

A composite ice-sand wedge about $0.5-1 \mathrm{~m}$ wide consisting of alternating $0.5-2 \mathrm{~cm}$ wide sand and ice stripes was studied in exposure Kha-3 (Fig. 6) about 300 m north of exposure Kha-2 and sampled for isotope studies at different levels. The ice wedge penetrates into sandy deposits. The lowermost part consists of yellowish-gray fine sand. Further up, the ice wedge traverses the already-described Peat Unit. The higher part of the section consists of grayish fine sand with numerous brownish and blackish spots and 
A
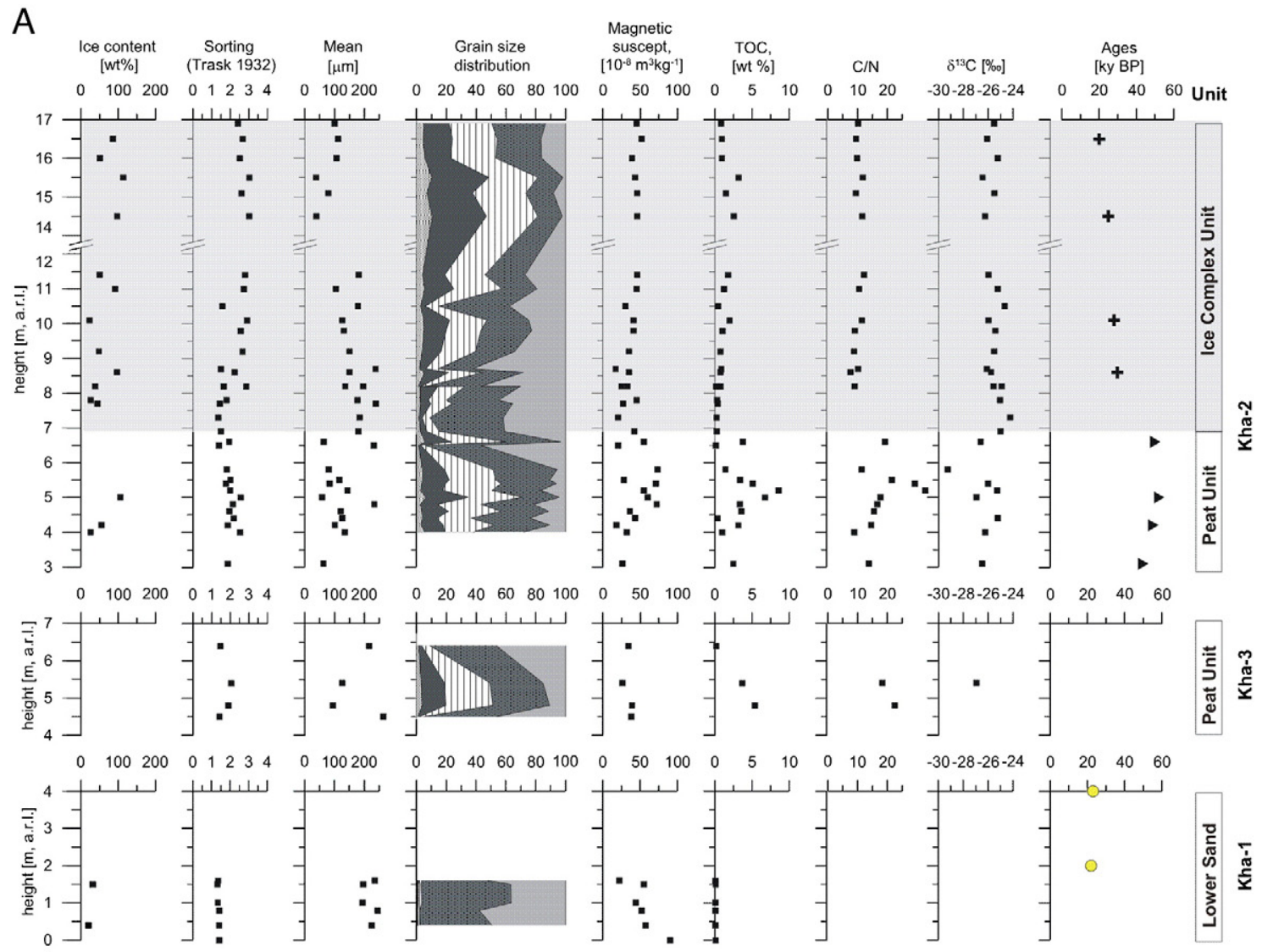

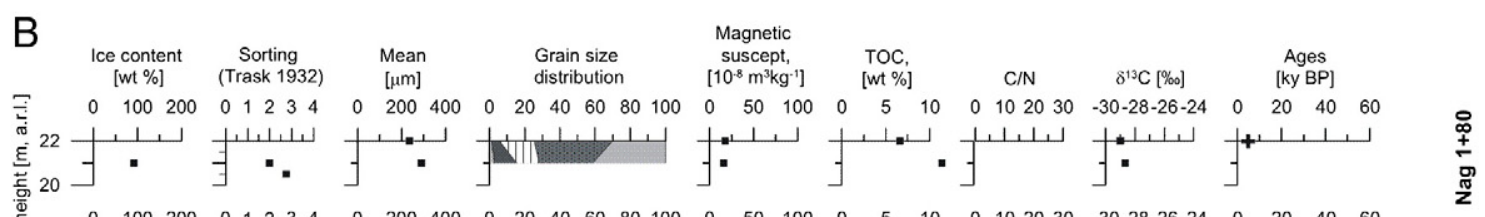
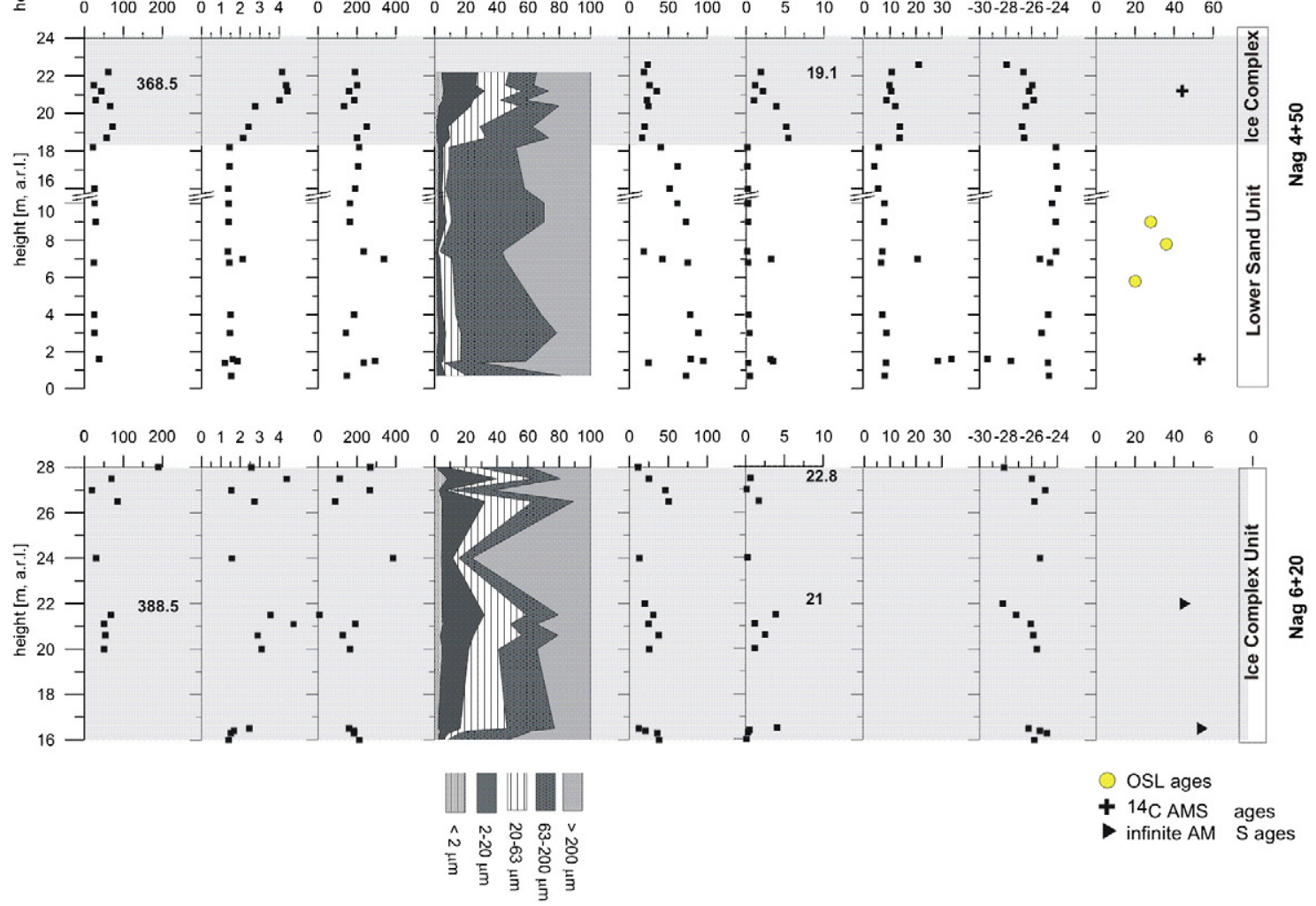

Fig. 7. Sediment data from exposures of the third Lena Delta terrace on (A) Khardang-Sise Island and (B) Nagym on Ebe-Basyn-Sise Island. 
small twig fragments. Ice belts concavely bent towards the ice wedge reflect syncryogenetic ice wedge formation.

On Khardang-Sise Island, the Lower Sand Unit, exposed in the Kha-1 section (up to $4 \mathrm{~m}$ a.r.l), is composed of almost organic-free well- to medium-sorted fine- to medium-grained sand (mean: 190$235 \mu \mathrm{m}$ ) with an MS of 20-90 SI (Fig. 7A). The sedimentological parameters are similar to those described earlier for Unit D. The peaty segment exposed between 3 and $6 \mathrm{~m}$ a.r.l. in section Kha-2A is characterized by poorly-sorted fine-grained sand to sandy silt (mean: $63-230 \mu \mathrm{m}$ ) with MS between 20 and 70 SI. Relatively high TOC values of $1-8.6 \mathrm{wt} . \%, \mathrm{C} / \mathrm{N}$ values of $9-29$, and $\delta^{13} \mathrm{C}$ values of -26.5 to $-29.9 \%$ reflect peat components at different stages of decomposition in these deposits. These deposits are not comparable to the alreadyclassified Units A-G and are therefore labeled as an additional Peat Unit (Fig. 7A). The sediments of section Kha-3 are also classified in the Peat Unit. The Ice Complex Unit further up consists of poorly- to verypoorly-sorted silty fine-grained sand with MS values between 20 and 55 SI. The TOC content ranges between 0.3 and $3.2 \mathrm{wt} . \%$ with $\delta^{13} \mathrm{C}$ values from -25.0 to $-26.5 \%$. The quite narrow $\mathrm{C} / \mathrm{N}$ ratio of $7.6-12.1$ reflects more highly decomposed organic matter. These features are caused by the existence of buried cryosol sequences within the Ice Complex sequence.

For completeness, several updated datasets from previouslystudied exposures from Nagym on Ebe-Basyn-Sise Island and Buor Khaya on Kurungnakh-Sise Island (Fig. 1B, C) that belong to the third Lena Delta terrace are included in this study (Fig. 8). These exposures showed a similar stratigraphic composition of sand deposits covered by Ice Complex deposits (Schirrmeister et al., 2003; Schwamborn et al., 2002c; Wetterich et al., 2008).

Finally, the already-mentioned exposure at the Nagym location (Fig. 1C) has a lithostratigraphical composition generally similar to that of the Khardang sequence (Fig. 7B). The well-sorted mediumgrained Lower Sand Unit is characterized by low TOC values of $0.2-$ $0.4 \mathrm{wt} . \%$, single plant detritus layers (TOC: $1.0-5.4 \mathrm{wt} . \%$ ), $\delta^{13} \mathrm{C}$ values of -24.1 to $-26.1 \%$, and MS values of $14-50$ SI (Fig. $7 \mathrm{~B}$ ). The covering Ice Complex Unit is composed of less-sorted fine- to medium-grained sand slightly coarser than that seen in Ice Complex deposits at Khardang-Sise Island (Fig. 7A). According to the geochronological results, this Ice Complex sequence is $>47.4-$ $44.2 \mathrm{kyr}$ BP old (Schirrmeister et al., 2003) and belongs to the MIS 3 stage.

\subsection{Geochronology}

\subsubsection{Age of the second Lena Delta terrace}

Radiocarbon and OSL dating was carried out from the Tur-2/Tur-1 deposits and the Ebe- 4 exposure (Figs. $1 \mathrm{C}$ and 3 ). In addition, previously-published IRSL ages from the LD98-D1 exposure are reviewed (Krbetschek et al., 2002; Schwamborn et al., 2002c).

The age-height correlation is generally good for the studied sequences on both sides of the Arynskaya Channel (Fig. 3, Table 1). The Tur- 2 core was radiocarbon-dated to between $>52 \mathrm{kyr}$ BP and $15.5 \pm 0.2 \mathrm{kyr}$ BP. One age inversion occurs in the uppermost part, probably caused by reworking processes at the beach level. The subsequent Tur- 1 exposure continues the radiocarbon age sequence between about $15.4 \pm 0.15 \mathrm{kyr}$ BP and $0.3 \pm 0.02 \mathrm{kyr}$ BP. One age discrepancy at $1.3 \mathrm{~m}(6.6 \pm 0.07 \mathrm{kyr} \mathrm{BP})$ was probably caused by contamination with Holocene plant matter in frost cracks. The radiocarbon age sequence of the Ebe- 4 exposure also covers the Lateglacial to late Holocene period with a gap between about 12.3 and 4.8 kyr BP.

The OSL ages of the Tur- 2 core and the Tur- 1 exposure also exhibit a good age-height correlation between $37 \pm 6 \mathrm{kyr}$ and $6 \pm 1 \mathrm{kyr}$ (Fig. 3, Table 2). Whereas OSL and radiocarbon ages correlate well in Tur- 1 , the older OSL ages in Tur-2 tend to be only half of the radiocarbon ages. The age difference in older parts can be as much as
20 kyr. Nevertheless, when summarizing the geochronological datasets we can narrow down the formation age of the cored sand sequence to the Middle to Late Weichselian period, while frozen sands in the lower segments of the Tur- 1 and Ebe- 4 exposures were formed during the Lateglacial period between 12.6 and $10.7 \mathrm{kyr}$ BP. This is in good agreement with IRSL feldspar ages of about 12-13.5 kyr BP for the sedimentologically and cryolithologically similar LD98-D1 exposure at Nikolay Lake (Fig. 5B, Tables 1 and 2). The Lateglacial sediments at the Arynskaya Channel are overlain by frozen Early to Middle-Holocene deposits, and finally covered by Late Holocene unfrozen sediments.

\subsubsection{Age of the third Lena Delta terrace}

The exposures at Khardang-Sise Island were also dated by radiocarbon and OSL methods (Fig. 8, Tables 1 and 2). The Lower Sand Unit of profile Kha-1 was OSL dated to about 23-22 kyr BP. The Peat Unit of profile Kha- 2 between 3 and $7 \mathrm{~m}$ a.r.l. shows infinite radiocarbon ages of $>52.1$ to $>43.5 \mathrm{kyr}$ BP. The overlying Ice Complex Unit was formed between 30 and $20 \mathrm{kyr}$ BP. A strong discrepancy between radiocarbon and OSL ages is apparent when the results of these methods are compared. However, it should be noted that subprofile Kha- 1 was only dated using OSL, whereas the radiocarbon ages refer to a set of subprofiles in the slightly-different Kha-2 sections (Fig. 8).

New OSL (quartz) age determinations on third terrace from the Lower Sand Unit in the Nagym (Ebe-Basyn-Sise Island) and Buor Khaya (Kurungnakh-Sise Island) exposures at the Olenyekskaya Channel (Table 3 ) were added in order to obtain a complete regional geochronological dataset. Samples were previously taken in 1998 and described in former publications (Krbetschek et al., 2002; Schirrmeister et al., 2003; Schwamborn et al., 2002c). These horizons were dated between $36 \pm 5 \mathrm{kyr}$ and $20 \pm 3 \mathrm{kyr}$ for the Nagym section and $54 \pm 9 \mathrm{kyr}$ and $30 \pm 5 \mathrm{kyr}$ for the Buor Khaya section (Fig. 8). The good age-height correlation within the new OSL ages is only marred by the youngest OSL age in the Nagym section. OSL ages from both sections are comparable to OSL results from the Khardang section. Nevertheless, OSL ages from both sites are significantly younger than the former IRSL age determinations on feldspars (Nagym 70-50 kyr; Buor Khaya 90-60 kyr; Fig. 8; Krbetschek et al., 2002). In these cases, the high errors indicate insufficient bleaching; such IRSL ages must be considered maximum estimates only (Krbetschek et al., 2002). Numerous radiocarbon ages of the overlying Ice Complex deposits contradict ages younger than $43 \mathrm{kyr}$ and indicate ages for the underlying Lower Sand Unit of $>57$ to $>43 \mathrm{kyr}$ BP in the Nagym section and 49 to $37 \mathrm{kyr}$ BP in Buor Khaya (Schirrmeister et al., 2003; Wetterich et al., 2008). We should realize that the application of different geochronological methods to permafrost deposits can result in large age differences although the specific method-related chronologies seem to show consistency within and between investigated sections.

\subsection{Mineralogical analysis}

About 60 samples from all exposures were studied for their heavy and light mineral compositions. Most of the studied heavy mineral grains of the fine fraction (63-125 $\mu \mathrm{m}$ ) are not or are only weakly rounded. The garnet grains always show angular shapes. Intergrowths of several minerals, e.g. feldspars with pyroxene or ilmenite, garnet with zircon or epidote, epidote with chlorite, and sphene with rutile are common. Rhombohedral pyroxenes consist of hypersthene. The monocline diopsides are variously colored. Augites seldom occur. Titanium minerals (ilmenite, sphene) are often transformed to leucoxene. Newly-formed siderite and rounded, probably reworked, iron hydroxides occur. These features allow us to infer the existence of relatively short transport paths and source areas with metamorphic basement. Mineral grains were partly affected by weathering and 


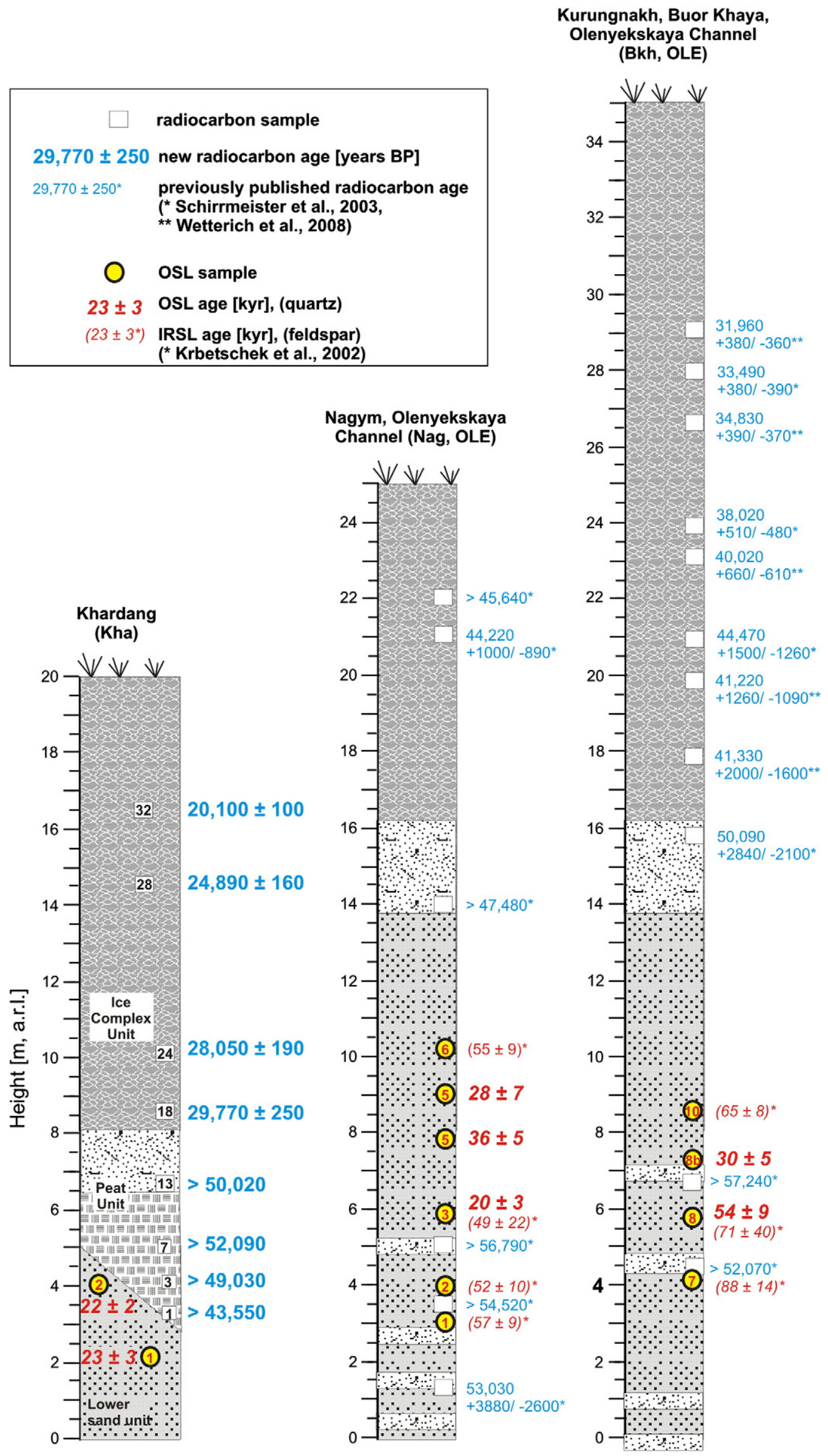


Table 2

OSL (quartz) dating results (new) and IRSL (feldspar) results ( ${ }^{*}$ Krbetschek et al., 2002) ( $\mathrm{D}_{\mathrm{e}}$ : equivalent dose; SD: standard deviation; $\mathrm{D}_{\text {rate: }}$ dose rate).

\begin{tabular}{|c|c|c|c|c|c|c|c|}
\hline OSL sample & Corresponding sediment sample & $\begin{array}{l}\text { Height } \\
\text { (masl) }\end{array}$ & Description & $\begin{array}{l}\text { Aliquots } \\
\text { (no.) }\end{array}$ & $\begin{array}{l}\mathrm{D}_{\mathrm{e}} \pm \mathrm{SD} \\
(\mathrm{Gy})\end{array}$ & $\begin{array}{l}\mathrm{D}_{\text {rate }} \\
(\mathrm{mG} / \mathrm{y})\end{array}$ & $\begin{array}{l}\text { OSL age } \\
(\mathrm{kyr})\end{array}$ \\
\hline \multicolumn{8}{|c|}{ Turakh-Sise Island (Arynskaya Channel) } \\
\hline Tur-OSL-1 & Tur-2-20 & -2.18 & Fine- to medium-grained sand & 28 & $19.4 \pm 4.0$ & 2.2 & $9 \pm 2$ \\
\hline Tur-OSL-5 & Tur-2-30 & -3.48 & Fine- to medium-grained sand & 14 & $32.4 \pm 3.9$ & 1.8 & $<18$ \\
\hline Tur-OSL-6 & Tur-2-46 & -4.98 & Medium-grained sand, organic-rich & 7 & $44.7 \pm 8.7$ & 1.9 & $24 \pm 6$ \\
\hline Tur-OSL-7 & Tur-2-84 & -8.23 & $\begin{array}{l}\text { Fine- to medium-grained sand, } \\
\text { peat inclusions }\end{array}$ & 27 & $84.0 \pm 13.2$ & 2.3 & $37 \pm 6$ \\
\hline Tur-OSL-4 & Tur-1-6 & 4.08 & $\begin{array}{l}\text { Fine- to medium-grained sand, } \\
\text { peat inclusions }\end{array}$ & 31 & $12.6 \pm 1.2$ & 2.1 & $6 \pm 1$ \\
\hline Tur-OSL-3 & Tur-1-3 & 2.88 & $\begin{array}{l}\text { Fine- to medium-grained sand, } \\
\text { organic patches }\end{array}$ & 12 & $25.8 \pm 2.2$ & 2.0 & $13 \pm 1$ \\
\hline Tur-OSL-2 & Tur-1-15 & 0.88 & Fine- to medium-grained sand & 29 & $23.4 \pm 2.3$ & 2.1 & $11 \pm 1$ \\
\hline \multicolumn{8}{|c|}{ Nikolay Lake (Arga-Muora-Sise Island) } \\
\hline ARG 5 & & 27.9 & Horizontally-bedded fine-grained sand & & $42 \pm 2.0$ & $3.23 \pm 0.23$ & $13.1 \pm 1.1$ \\
\hline ARG 4 & & 27.3 & Horizontally-bedded fine-grained sand & & $39 \pm 2.4$ & $3.24 \pm 0.22$ & $12.0 \pm 1.1 *$ \\
\hline ARG 3 & & 26.6 & Horizontally-bedded fine-grained sand & & $40 \pm 3.9$ & $3.04 \pm 0.17$ & $13.3 \pm 1.5$ \\
\hline ARG 1 & & 25.1 & Horizontally-bedded fine-grained sand & & $50 \pm 2.6$ & $3.74 \pm 0.11$ & $13.4 \pm 1.1$ \\
\hline \multicolumn{8}{|c|}{ Khardang-Sise Island (Arynskaya Channel) } \\
\hline Kha-OSL-2 & & 4.0 & $\begin{array}{l}\text { Fine- and medium-grained-sand, } \\
\text { fine-bedded }\end{array}$ & 31 & $51.6 \pm 5.2$ & 2.2 & $23 \pm 3$ \\
\hline Kha-OSL-1 & & 2.0 & $\begin{array}{l}\text { Fine- and medium-grained-sand, } \\
\text { fine-bedded }\end{array}$ & 24 & $49.8 \pm 3.3$ & 2.3 & $22 \pm 2$ \\
\hline \multicolumn{8}{|c|}{ Nagym (Ebe-Basyn-Sise Island) } \\
\hline Ole-5 & & 9.0 & Fine-grained sand & 26 & $72.2 \pm 14.3$ & 2.6 & $28 \pm 7$ \\
\hline Ole-4 & & 7.8 & Fine-grained sand & 25 & $98.9 \pm 8.8$ & 2.7 & $36 \pm 5$ \\
\hline Ole-3 & & 5.8 & Fine-grained sand, silty interbeds & 34 & $39.3 \pm 3.4$ & 2.0 & $20 \pm 3$ \\
\hline \multicolumn{8}{|c|}{ Buor Khaya (Kurungnakh-Sise Island) } \\
\hline Ole-8b & & 7.2 & $\begin{array}{l}\text { Fine-grained sand, silty and } \\
\text { medium-grained interbeds }\end{array}$ & 15 & $69.6 \pm 7.1$ & 2.3 & $30 \pm 5$ \\
\hline Ole-8 & & 5.7 & Fine-grained sand, partly cryoturbated & 18 & $110.1 \pm 11.3$ & 2.0 & $54 \pm 9$ \\
\hline
\end{tabular}

pedogenic processes. Because of the similar heavy mineral associations in the fine and the coarse fractions, the presentation of analytical results is focused on the more-representative finer fraction. The only difference is the grain roundness. In samples from Ebe-Basyn-Sise Island the coarser grains are only weakly- or non-rounded. In contrast, the coarser grains from Turakh-Sise Island and Khardang-Sise Island exposures are mostly sub-rounded but seldom well-rounded or nonrounded.

On the Arga Complex, the mineralogical composition differs significantly for the segment of Units $A, B_{1}, C$, and $B_{2}$ in the Tur-2 core down to a depth of $-4.38 \mathrm{~m}$ b.r.l., which is characterized by higher mica contents in the heavy $(0.3-1.2 .9 \%)$ as well as the light (0.3-3.5\%) fractions (SOM-3, Table 3 ); this higher mica content is correlated with the high MS of these units (Fig. 4). Unit A is additionally marked by the highest zircon and garnet contents (Table 3). Variations in the mineral composition of both the covering Unit D and Unit $\mathrm{E}$ are on a similar scale. This is also true for samples from the T-021 exposure on Turakh-Sise Island and Ebe-4, Ebe-2, Ebe3, and Ebe-5 on Ebe-Basyn-Sise Island (SOM-3). The mineralogical similarities of Units D, E, F, and G probably reflect similar sediment sources for these Arga Complex deposits.

In third terrace deposits there are no significant differences between the heavy mineral signatures from the Lower Sand Unit and the Ice Complex Unit on Khardang-Sise Island, or from the Nagym site at the southern rim of Ebe-Sise Island (SOM-3, Table 3). Smaller variations could be caused by different accumulation conditions and postsedimentary cryogenic and pedogenic modifications. However, clear differences are evident between the Lower Sand Unit and the covering Ice Complex Unit at the Buor Khaya site on Kurungnakh-Sise Island. This is especially reflected in higher garnet and epidote contents as well as lower pyroxene and amphibole contents of the Ice Complex deposits (Table 3), a distribution that is similar to brook sediments from Chekanovsky Ridge (Schwamborn et al., 2002c). Therefore, the nearby Chekanovsky Ridge is considered to be the source area for the Ice Complex deposits on Kurungnakh-Sise Island. However, the heavy mineral composition of the Lower Sand Unit at Kurungnakh-Sise Island is comparable to all the other samples mentioned earlier. The source areas for all deposits with similar heavy mineral signatures should be similar, and should correspond to the integral heavy mineral signature of the modern Lena River deposits (Schwamborn et al., 2002c). Therefore, the Lena River catchment is considered to be the sediment source for deposits of the second and partly of the third Lena Delta terraces.

\subsection{Stable water isotopes of ground ice}

In various types of ground ice the stable isotope composition $\left(\delta^{18} \mathrm{O}, \delta \mathrm{D}, d\right.$-excess) has been determined for studying ice differentiation, stratigraphical correlation, and postcryogenic alteration. Furthermore, paleoenvironmental interpretation concerning winter precipitation that fed ice wedges has been undertaken. The corresponding sample positions are shown in the exposure schemes (Figs. 3, 5 and 6, SOM-2).

All the ice veins of the Tur-1, Ebe-2, Ebe-4, Ebe-5, and LD-98 D-1 exposures in the Arga Complex have similar isotope signatures that are heavier (less negative) than that of the Khardang ice wedges (Table 4 ) and correlate very well $\left(R^{2}=0.98\right)$ with a slope of 7.2 and an intercept of -10.3 , close to the GWML (Fig. 9A). This isotope signature reflects a similar genesis of the ice veins in Unit $\mathrm{E}$ of the Arga Complex. Texture ice values from the Tur-2 core correlate well $\left(R^{2}=0.99\right)$ with a slope of 9.3 and an intercept of 32.8 below the

Fig. 8. Radiocarbon and OSL ages of the exposures at Khardang-Sise (Kha), Ebe Basyn Sise (Nagym), and Kurungnakh-Sise (Bkh) islands. *OSL samples were taken in 1998 (Krbetschek et al., 2002) from different profiles; due to erosion of river banks, these positions might not be identical with positions sampled in 2000. Radiocarbon ages are marked in blue while OSL and IRSL ages are marked in red. 
Table 3

Heavy mineral compositions (in grain percent) of the classified sediment units in the combined Tur-2/Tur-1 sequence and in the other exposures (mean, min-max); the Ice Complex Unit on Kurungnakh Island is marked in gray.

\begin{tabular}{|c|c|c|c|c|c|c|c|c|c|}
\hline & Ilmenite & Epidote & Pyroxene & Amphibol & Garnet & Zircon & Apatite & Sphene & $n$ \\
\hline \multirow[t]{2}{*}{ Tur-2, Unit A } & 21.8 & 15.8 & 21.7 & 40.0 & 14.7 & 5.1 & 2.7 & 6.3 & 3 \\
\hline & $14.0-29.4$ & $11.3-20.7$ & $15.0-27.2$ & $28.5-44.3$ & $10.1-16.9$ & $3.6-7.3$ & $2.3-4.7$ & $5.2-7.2$ & \\
\hline \multirow[t]{2}{*}{ Tur-2, Unit $\mathrm{B}_{1}$} & 10.1 & 20.6 & 18.9 & 42.4 & 8.3 & 1.6 & 3.0 & 5.1 & 5 \\
\hline & $7.3-14.2$ & $17.2-24.8$ & $11.0-22.0$ & $38.7-45.7$ & $5.6-10.5$ & $1.1-2.1$ & $1.7-4.4$ & $3.2-7.1$ & \\
\hline \multirow[t]{2}{*}{ Tur-2, Unit C } & 8.0 & 15.0 & 19.4 & 49.4 & 6.8 & 1.5 & 3.8 & 4.1 & 4 \\
\hline & 3.9-13.1 & $12.1-19.9$ & $16.2-20.9$ & $42.7-60.9$ & $3.1-10.3$ & $0.8-2.8$ & $3.1-4.8$ & $2.0-6.8$ & \\
\hline \multirow{2}{*}{ Tur-2, Unit $\mathrm{B}_{2}$} & 7.7 & 19.6 & 20.4 & 43.1 & 8.2 & 1.0 & 2.3 & 5.5 & 9 \\
\hline & $5.2-14.9$ & $15.2-22.9$ & $16.2-24.5$ & $37.9-48,4$ & $4.2-13.8$ & $0.3-1.8$ & $1.3-3.5$ & $3.1-9.7$ & \\
\hline \multirow[t]{2}{*}{ Tur-1, -2, Unit D } & 12.3 & 14.5 & 23.0 & 41.9 & 11.2 & 1.3 & 2.5 & 5.5 & 13 \\
\hline & $6.7-17.7$ & $10.6-23,3$. & $17.4-28.2$ & $38.2-45.2$ & $8.1-14.9$ & $0.4-2.7$ & $1.1-6.8$ & $3.7-7.2$ & \\
\hline \multirow[t]{2}{*}{ Tur-1, Units E, F, and G } & 10.9 & 13.9 & 26.8 & 39.7 & 10.9 & 1.0 & 2.3 & 5.2 & 4 \\
\hline & $7.6-13.8$ & $10.6-17.1$ & $23.2-30.2$ & $35.2-43.2$ & $7.9-13.8$ & $0.6-1.3$ & $1.5-3.0$ & $3.7-6.1$ & \\
\hline \multirow[t]{2}{*}{ Ebe-2 } & 11.0 & 15.9 & 22.1 & 41.9 & 9.0 & 1.9 & 3.6 & 5.2 & 3 \\
\hline & $9.7-12.5$ & $12.3-18.2$ & $19.5-24.5$ & $40.8-44.4$ & $7.5-10.9$ & $1.1-2.5$ & $2.8-4.4$ & $4.1-7.2$ & \\
\hline \multirow[t]{2}{*}{ Ebe-4 } & 13.6 & 12.0 & 24.2 & 45.4 & 10.5 & 1.3 & 2.5 & 4.2 & 5 \\
\hline & $9.7-17.9$ & $10.4-13.6$ & $20.3-23.7$ & $41.1-51,9$ & $7.8-13.2$ & $0.4-2.4$ & $1.2-3.5$ & $3.1-5.2$ & \\
\hline \multirow[t]{2}{*}{ Ebe-5 } & 9.7 & 14.1 & 22.1 & 44.9 & 8.5 & 1.6 & 2.2 & 5.8 & 3 \\
\hline & $8.7-10.6$ & $12.7-15.3$ & $21.2-23.1$ & $41.8-48.0$ & $6.8-11.3$ & $1.1-2.1$ & $1.8-2.5$ & $5.6-6.0$ & \\
\hline \multirow[t]{2}{*}{ Arga, D1 } & 13 & 11.8 & 24.6 & 32.3 & 12.4 & 0.9 & 4.1 & 0.9 & 3 \\
\hline & $12.3-13.6$ & $9.0-15.0$ & $16.7-33.0$ & $31.6-33$ & $9.8-16.0$ & $0.0-1.8$ & $3.0-6.2$ & $0.0-2.0$ & \\
\hline \multirow[t]{2}{*}{ Tur-021 } & 6.6 & 10.5 & 28.5 & 48.4 & 5.9 & 0.1 & 1.1 & 4.8 & 3 \\
\hline & $5.3-8.0$ & $9.0-12.7$ & $25.5-32.0$ & $45.5-51.6$ & $4.0-9.2$ & - & $0.7-2.7$ & $3.5-5.7$ & \\
\hline \multirow[t]{2}{*}{ Kha-2, Ice Complex Unit } & 6.0 & 15.9 & 18.2 & 42.2 & 8.5 & 0.9 & 3.4 & 5.0 & 8 \\
\hline & $4.5-7.1$ & $13.0-20.9$ & $11.1-21.4$ & $31.6-47.9$ & $3.6-13.4$ & $0.3-2.3$ & $2.3-4.6$ & $3.9-11.7$ & \\
\hline \multirow[t]{2}{*}{ Kha-1, Lower Sand Unit } & 10.0 & 13.8 & 18.7 & 44.7 & 6.4 & 0.9 & 2.9 & 3.6 & 3 \\
\hline & $6.6-14.9$ & $11.1-15.3$ & $16.5-19.8$ & $37.1-49.7$ & $5.9-6.9$ & $0.3-1.5$ & $1.8-4.4$ & $3.3-4.0$ & \\
\hline \multirow[t]{2}{*}{ Nagym, Ice Complex Unit } & 6.6 & 16.4 & 11.4 & 41.0 & 14.0 & 2.3 & 2.2 & 6.1 & 4 \\
\hline & $4.8-10.2$ & $15.2-19.3$ & $7.6-17.6$ & $28.4-50.8$ & $10.2-17.9$ & $0.7-3.5$ & $0.3-4.6$ & $3.6-9.0$ & \\
\hline \multirow[t]{2}{*}{ Nagym, Lower Sand Unit } & 5.0 & 13.1 & 13.1 & 48.2 & 10.6 & 1.4 & 3.8 & 4.8 & 6 \\
\hline & $2.1-7.5$ & $11.7-14.2$ & $11.1-15.4$ & $42.4-52.1$ & $6.1-15.7$ & $0.3-2.7$ & $2.0-6.8$ & $3.2-7.4$ & \\
\hline \multirow[t]{2}{*}{ Buor Khaya, Ice Complex Unit } & 2.5 & 30.8 & 6.7 & 10.3 & 34.3 & 1.1 & 5.5 & 8.9 & 5 \\
\hline & $0.8-5.7$ & $25.6-36.5$ & $1.9-9.8$ & $2.9-15.6$ & $31.2-36.9$ & $0.7-1.7$ & $3.9-7.3$ & $5.1-12.1$ & \\
\hline \multirow[t]{2}{*}{ Buor Khaya, Lower Sand Unit } & 12.0 & 10.7 & 21.8 & 33,2 & 15.1 & 1.1 & 1.9 & 4.1 & 5 \\
\hline & $6.8-16.9$ & $8.8-12.6$ & $17.6-29.9$ & $30.2-38.2$ & $14.9-26.0$ & $0.3-1.5$ & $0.8-3.9$ & $1.8-5.9$ & \\
\hline
\end{tabular}

GMWL over a wide range (Table 4). The heaviest isotope composition was measured in texture ice of the Tur- 1 and Ebe- 4 exposures.

The lightest (most negative) stable isotope composition was measured on the third terrace in the composite sand-ice wedge of section Kha-3 from the Ice Complex Unit of Khardang-Sise Island (Fig. 9A, Table 4). The data correlate very well $\left(R^{2}=0.98\right)$, with a slope of 6.6 and an intercept of -39.5 , and plot below the GMWL. The data from small ice veins in nearby section Kha-2 B fit this dataset well. The $d$-excess of the Khardang ground ice is rather low (4.0 to $-1.2 \%$ ). The isotope signature is similar to those of Ice Complex ice wedges from the Nagym site (Schirrmeister et al., 2003) and from Kurungnakh-Sise Island (Wetterich et al., 2008). Texture ice samples

Table 4

Stable isotope signatures in various ground ice samples from the second and third terraces of the Lena Delta (mean, max to min).

\begin{tabular}{|c|c|c|c|c|}
\hline Ground ice sample & $\mathrm{N}$ & $\begin{array}{l}\delta^{18} \mathrm{O} \\
\text { (VSMOW, \%。) }\end{array}$ & $\begin{array}{l}\text { §D } \\
\text { (VSMOW, \% ) }\end{array}$ & $\begin{array}{l}d \text {-excess } \\
(\%)\end{array}$ \\
\hline Kha-3 ice wedge & 10 & $\begin{array}{l}-30.1 \\
(-27.4 \text { to }-32.0)\end{array}$ & $\begin{array}{l}-239.3 \\
(-222.2 \text { to }-252.3)\end{array}$ & $\begin{array}{l}1.2 \\
(4.0 \text { to }-3.5)\end{array}$ \\
\hline Kha-2 ice wedge & 3 & $\begin{array}{l}-27.4 \\
(-26.3 \text { to }-27.9)\end{array}$ & $\begin{array}{l}-217.9 \\
(-211.8 \text { to }-221.0)\end{array}$ & $\begin{array}{l}1.0 \\
(2.2 \text { to }-1.2)\end{array}$ \\
\hline Tur-1 ice wedge & 14 & $\begin{array}{l}-22.9 \\
(-18.9 \text { to }-25.3)\end{array}$ & $\begin{array}{l}-175.9 \\
(-144.6 \text { to }-192.6)\end{array}$ & $\begin{array}{l}7.0 \\
(10.0 \text { to } 3.9)\end{array}$ \\
\hline D1 ice wedge & 4 & $\begin{array}{l}-24.5 \\
(-21.0 \text { to }-26.1)\end{array}$ & $\begin{array}{l}-188.0 \\
(-162.1 \text { to }-198.3)\end{array}$ & $\begin{array}{l}8.2 \\
(10.2 \text { to } 5.8)\end{array}$ \\
\hline Ebe- 4 ice wedge & 3 & $\begin{array}{l}-22.0 \\
(-20.8 \text { to }-23.9)\end{array}$ & $\begin{array}{l}-170.3 \\
(-164.2 \text { to }-178.9)\end{array}$ & $\begin{array}{l}6.0 \\
(12.7 \text { to } 2.4)\end{array}$ \\
\hline Ebe-5 ice wedge & 2 & $\begin{array}{l}-23.0 \\
(-21.0 \text { to }-24.9)\end{array}$ & $\begin{array}{l}-173.8 \\
(-158.5 \text { to }-189.1)\end{array}$ & $\begin{array}{l}9.9 \\
(10.3 \text { to } 9.4)\end{array}$ \\
\hline Ebe-2 ice wedge & 3 & $\begin{array}{l}-22.2 \\
(-21.9 \text { to }-22.5)\end{array}$ & $\begin{array}{l}-170.1 \\
(-167.9 \text { to }-172.0)\end{array}$ & $\begin{array}{l}7.7 \\
\text { ( } 7.9 \text { to } 7.4 \text { ) }\end{array}$ \\
\hline Kha-1 crack & 1 & -27.04 & -205.5 & 10.8 \\
\hline Kha-2 texture ice & 14 & $\begin{array}{l}-25.6 \\
(-23.9 \text { to }-26.94)\end{array}$ & $\begin{array}{l}-195.0 \\
(-181.4 \text { to }-216.5)\end{array}$ & $\begin{array}{l}9.8 \\
(20.5 \text { to }-1.4)\end{array}$ \\
\hline Kha-3 texture ice & 1 & -23.70 & -193.3 & -3.6 \\
\hline Tur- 1 texture ice & 3 & $\begin{array}{l}-18.3 \\
(-17.5 \text { to }-18.5)\end{array}$ & $\begin{array}{l}-138.9 \\
(-136.9 \text { to }-142.6)\end{array}$ & $\begin{array}{l}5.5 \\
\text { (8.7 to } 2.6)\end{array}$ \\
\hline Tur-2 texture ice & 6 & $\begin{array}{l}-25.1 \\
(-21.9 \text { to }-26.3)\end{array}$ & $\begin{array}{l}-201.09 \\
(-170.7 \text { to }-212.1)\end{array}$ & $\begin{array}{l}-0.2 \\
(4.4 \text { to }-1.7)\end{array}$ \\
\hline Ebe- 4 texture ice & 2 & $\begin{array}{l}-18.4 \\
(-18.2 \text { to }-18.5)\end{array}$ & $\begin{array}{l}-144.91 \\
(-144.2 \text { to }-145.6)\end{array}$ & $\begin{array}{l}2.1 \\
\text { (1.8 to } 2.3 \text { ) }\end{array}$ \\
\hline
\end{tabular}




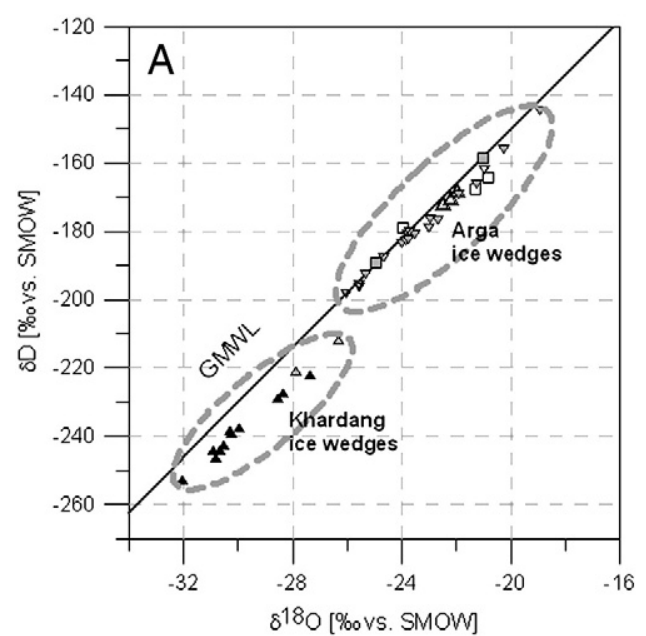

$\triangle$ Kha-2 ice wedge $\nabla$ D-1 ice wedge $\square$ Ebe-4 ice wedge

$\Delta$ Kha-3 ice wedge $\nabla$ Tur-1 ice wedge $\Delta$ Ebe-2 ice wedge

Ebe- 5 ice wedge

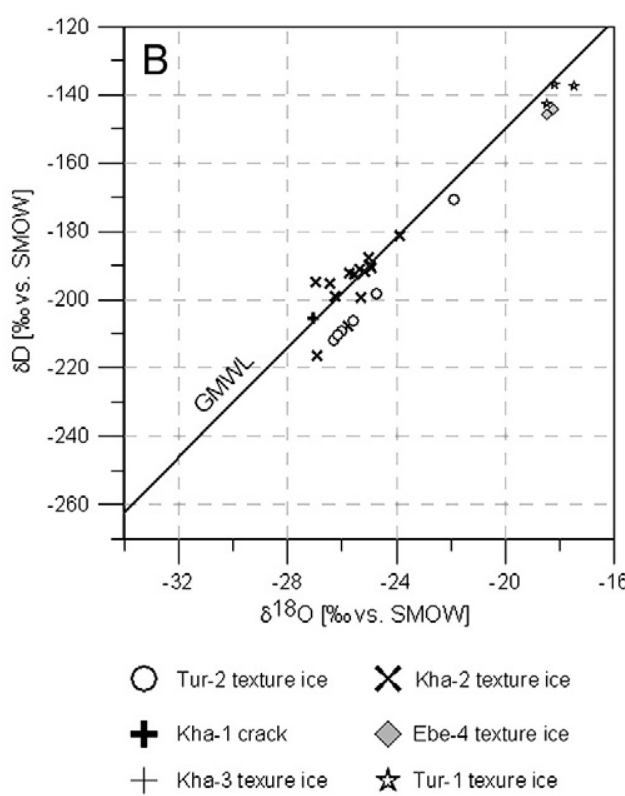

+ Kha-3 texure ice \& Tur-1 texure ice

Fig. 9. $\delta D-\delta{ }^{18} \mathrm{O}$ cross plot for various ground ice samples from the second and third Lena Delta terraces showing data from (A) ice wedges and (B) texture ice.

from the Ice Complex Unit on Khardang-Sise Island scatter for $\delta^{18} \mathrm{O}$ between -23.9 and $-26.9 \%$ and for $\delta \mathrm{D}$ between -181.4 and $-216.5 \%$, both above and below the GMWL without any clear correlation (Fig. 9B).

In general, both types of ground ice show the same pattern of lighter isotope composition (Fig. 9) in late Pleistocene ground ice reflecting formation under colder conditions, and heavier isotope composition in Lateglacial and Holocene ground ice that formed under warmer conditions.

\subsection{Paleoecology}

\subsubsection{Pollen records}

On the Arga Complex, pollen are almost absent in the Tur-2 core sequence. Only single grains of Poaceae and reworked Pinaceae were found in a few samples except for deposits between -5 and $-6 \mathrm{~m}$ depth. Their spectra are dominated by Poaceae pollen with a few Artemisia, Asteraceae, Cyperaceae, Brassicaceae, and some other herbs. Higher amounts of reworked coniferous taxa (Pinus s/g Haploxylon, Larix, Picea, and Abies) are also notable. Coprophilous fungi spores (Sporormiella, Sordaria, and Podospora) are common. Generally, these spectra are similar to the Ice Complex pollen assemblages from Khardang-Sise Island (pollen zone III, PZ-III, Fig. 10B) and reflect similar vegetation conditions.

The sediments from the Tur- 1 exposure above the Tur- 2 core are rich in pollen (Fig. 10A). The oldest pollen spectrum (PZ-I), radiocarbon-dated to ca $10.8 \mathrm{kyr} \mathrm{BP}$, is dominated by Betula sect. Nanae, Cyperaceae, and Poaceae pollen, pointing to the rather warm and wet local environment typical at the end of the Allerød. The similarly-dated terrestrial pollen records from the Laptev Sea region are also characterized by higher contents of birch pollen in the betterprotected inland areas (e.g. Andreev et al., 2003; Grosse et al., 2007; Makeyev et al., 2003; Pisaric et al., 2001). In the following PZ-II, only a few Encalypta and Lycopodium spores as well as reworked ancient Pinaceae were found, reflecting unfavorable vegetation conditions during the Younger Dryas cold interval. The PZ-III above (ca 9.1 kyr BP) is characterized by a very high pollen concentration dominated by Betula, Alnus fruticosa, Ericales, Cyperaceae, and Poaceae, reflecting shrub tundra during the early Holocene. Paleoclimate reconstructions conducted on pollen and chironomid records from nearby Nikolay Lake show that temperatures in this part of the Arctic were up to $4{ }^{\circ} \mathrm{C}$ higher at that time than they are nowadays (Andreev et al., 2004). The pollen spectrum of PZ-IV (ca 0.7 kyr BP) is dominated by Salix and Cyperaceae pollen, reflecting the modern willow- and sedge/grass-dominated tundra vegetation. Pollen concentration is quite low. Tree and shrub pollen (mostly Picea, Larix, and Pinus) in this spectrum are of longdistance wind-transported origin. The uppermost PZ-V, dated ca $0.3 \mathrm{kyr} \mathrm{BP}$, is characterized by a very low pollen concentration and poor pollen preservation and could not be used for the environmental reconstructions.

On Khardang-Sise Island (third terrace), only single Poaceae and Cyperaceae pollen and a few reworked ancient coniferous pollen were found in the Lower Sand Unit (Fig. 10B, PZ-I, 0-1.6 m a.r.l.). The Peat Unit (subprofile Kha-2 A), radiocarbon-dated to an infinite age (Table 2), is dominated by Cyperaceae pollen with a few Poaceae (PZ-II, 3.1-8.3 $\mathrm{m}$ a.r.l.). There are rather numerous well-preserved pollen grains of Pinus s/g Haploxylon and Larix with few other tree and shrub pollen types. High amounts of reworked ancient coniferous taxa are also notable in this zone. We assume that the sediments accumulated during the early MIS 3 Interstadial. Although tree pollen are numerous in PZ-II it is very unlikely that trees like larch or Siberian pine (Pinus sibirica) or shrubs like stone pine (Pinus pumila) could grow in the area. The permanent presence of relatively thermophilic coniferous trees like Picea, Abies, and especially Tsuga in the pollen spectra, points to the reworked character of the tree fraction. The tree taxa are probably present due to long-distance transport by the Lena River from the southern Yakutian hinterland. Numerous Cyperaceae pollen dominating in PZ-II reflect a relatively wet local environment with sedge vegetation during the MIS 3 . The Ice Complex Unit, radiocarbondated to between 30 and $20 \mathrm{kyr}$ BP (subprofiles Kha-2 B-E), is dominated by Poaceae pollen with some Cyperaceae, Artemisia, and a few other herbs (PZ-III, 8.3-16.5 m a.r.l.). High amounts of reworked ancient coniferous pollen (mostly Pinus s/g Haploxylon and Larix) are also notable for this zone. Pollen assemblages reflect an open, predominantly grass-sedge steppe-like environment. Coprophilous fungi spores (Sporormiella, Sordaria, and Podospora) are numerous in the lower part of the zone, indirectly pointing to the presence of grazing mammals in the area.

Generally, the lower sediments from the Nagym site are characterized by predominantly low pollen concentration and numerous reworked pollen. Therefore, these data are not suitable for paleoenvironmental interpretations. The Lower Sand Unit and 

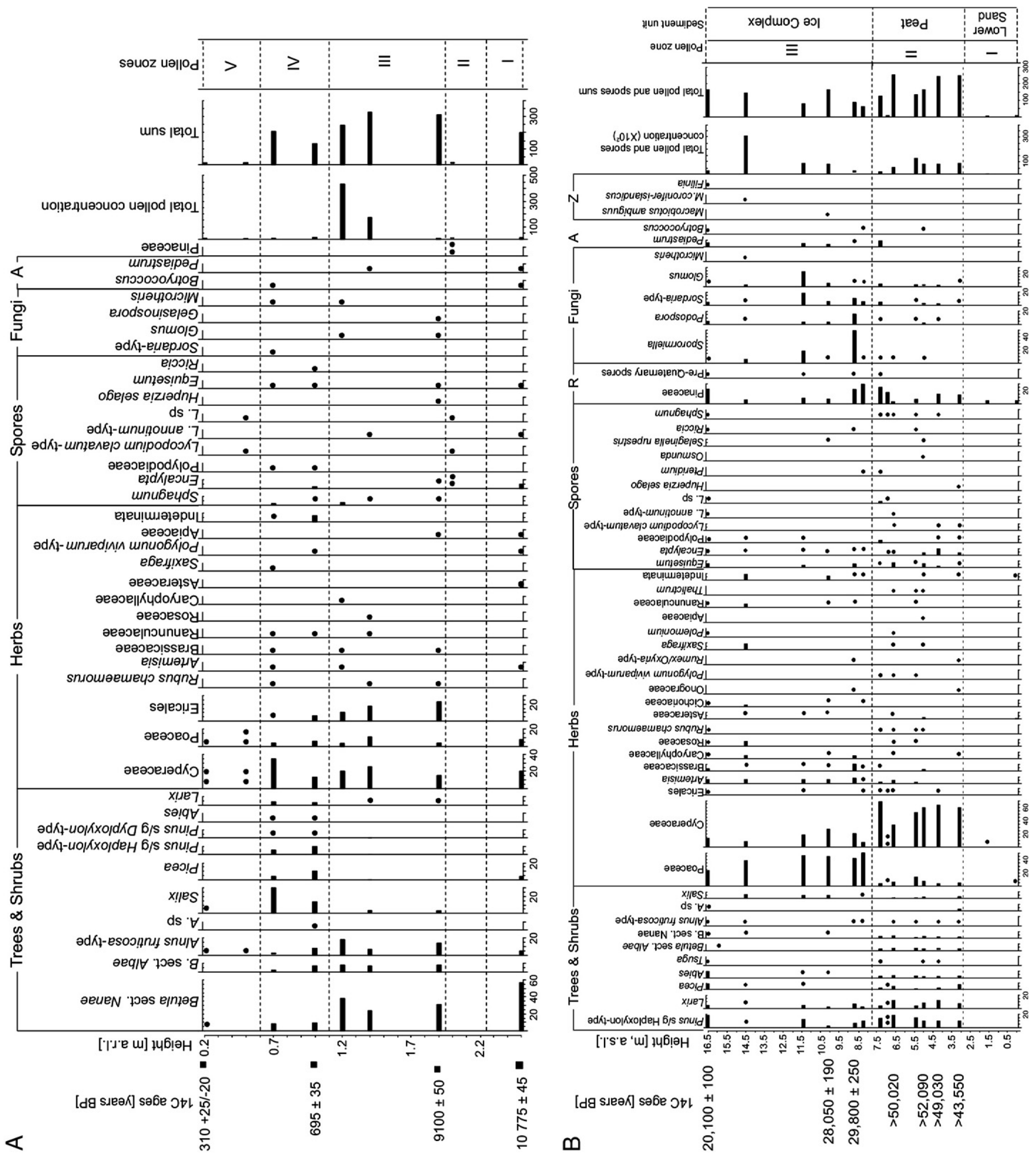


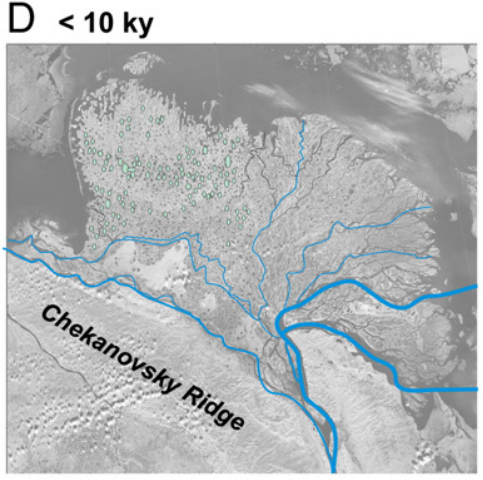

\section{2nd terrace area (Arga Complex)}

aeolian sand

(dune)

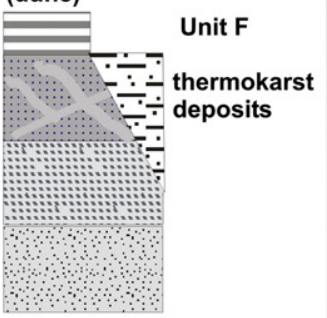

C 12 to $10 \mathrm{ky}$

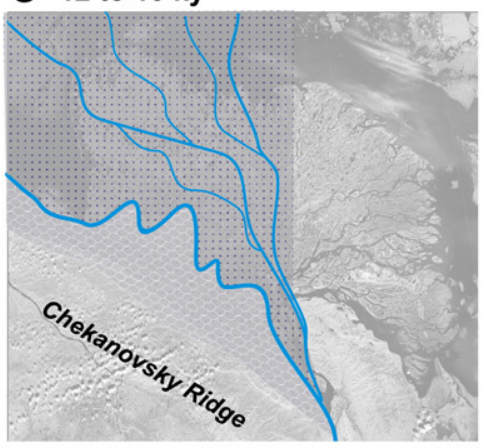

B 50 to $12 \mathrm{ky}$

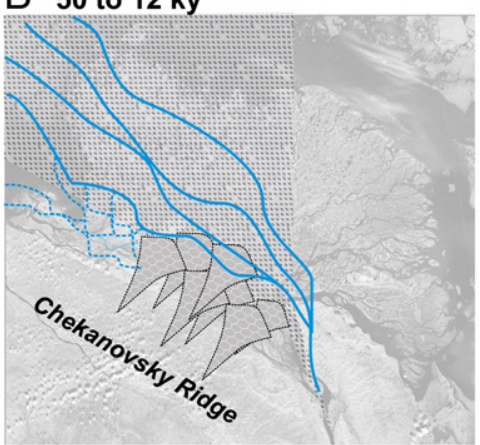

sandy sediments

of an anastomazing

river system

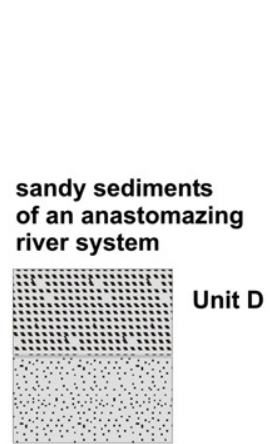

subaerial sand deposit modified by cryogenesis and pedogenesis

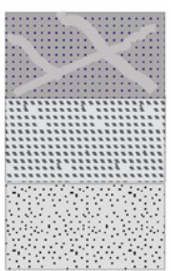

Unit E

proluvial deposits

from the Chekanovsky

Ridge + floodplain deposits

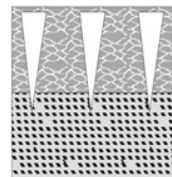
Unit

\section{A 100 to $50 \mathrm{ky}$}

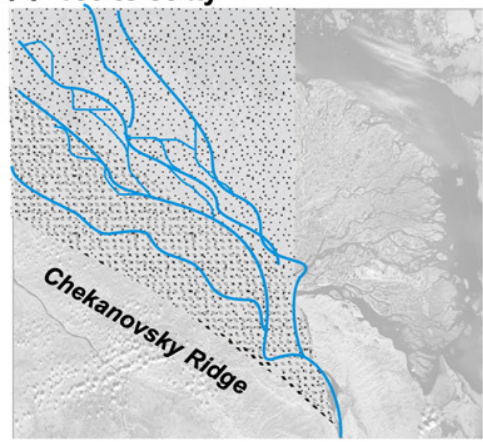

sandy sediments of an braided river system

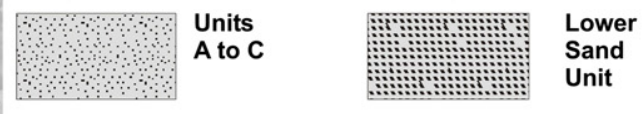

Fig. 11. Paleogeographic scheme of the late Quaternary landscape dynamics in the western Lena Delta area. (A) Early Weichselian, (B) Middle to late Weichselian, (C) Lateglacial, and (D) Holocene landscapes.

lower segments of the Ice Complex Unit contain mostly reworked pollen of Abies, Pinus, Picea, and Larix. The studied pollen spectra are very similar to PZ-I of Khardang section 1 (Fig. 10B). The upper segment of the Ice Complex Unit contains the typical MIS 3 pollen association dominated by Cyperaceae and Poaceae with numerous
Artemisia and Caryophyllaceae and single Salix, Fabaceae, and Valeriana pollen. The Holocene cover deposits on top of the Ice Complex, radiocarbon-dated to about $5 \mathrm{kyr}$, are dominated by pollen of Betula sect. nana and Alnus fruticosa and a few Cyperaceae, Poaceae, and Artemisia pollen.

Fig. 10. Pollen records from the western Lena Delta: (A) Pollen diagram from the Lateglacial to Holocene Tur-1 exposure on Turakh-Sise Island; (B) Pollen diagram of the Ice Complex Kha-2 exposure on Khardang-Sise Island ( $\mathrm{R}$ - reworked; $\mathrm{A}$ - algae; $\mathrm{Z}$ - zoological remains). 


\subsubsection{Plant macrofossil records}

Plant macrofossil studies of third terrace sequences were conducted at the Nagym section in a continuation of similar studies at Kurungnakh-Sise Island (Wetterich et al., 2008). Both sequences contained well-preserved plant remains, which fluctuated in abundance and diversity depending on taphonomical conditions. Altogether, 62 plant taxa could be identified in the Nagym section (SOM-4). The sharp sedimentological boundary between the Lower Sand and the Ice Complex units is not clearly detectable in the plant macrofossil record (SOM-5), indicating that the change in the hydrological system resulting in altered sedimentation did not result in general changes of the vegetation. For example, plants typical of the Arctic, characteristically found in snow beds and tundra wetlands, and arctic pioneer vegetation, as well as species from steppes and Kobresia mats that occur at dry places in the Arctic, were found in both units (SOM-5). The main difference between these units was a higher percentage of thermophilous plants in the early Weichselian fluvial sands, many of them typical of freshwater and littoral habitats likely correlated with their subaquatic deposition. The littoral plants indicate water level fluctuations, likely correlated with strong seasonal paleo-Lena River discharge variations, which are characteristic of arctic rivers. Some littorals, such as Rumex maritimus, Tripleurospermum hookeri, and Ranunculus sceleratus, indicate fluctuating salt concentration, which might signify a high rate of evaporation. Possibly, the remains of some southern extralimital plants were introduced by the paleo-Lena River from the Yakutian hinterland. For example, we have found Rubus cf. idaeus, Fragaria sp., and Stellaria longifolia, which are restricted to the forest zone in Yakutia. Together with Chamadaphne calyculata and Duschekia fruticosa, they also might indicate the proximity of subarctic shrubbery during certain times of Lower Sand Unit deposition.

In the Ice Complex Unit, the percentage of plants occurring in dry places, e.g. in steppes and Kobresia mats, increases distinctly. Such vegetation existed on accumulation plains formed under the arid cold-stage Siberian Arctic climate. The plant macrofossil record is similar to other late Pleistocene cold-stage assemblages in the Laptev Sea region (Kienast et al., 2005; Wetterich et al., 2008).

\subsubsection{Testate amoebae records}

Testate amoebae (Testacea) are shell-bearing rhizopods that reflect varying subsurface conditions, e.g. moisture and temperature, in soils and small shallow water bodies. The preservation of these small thin shells indicates in situ (non-reworked) accumulation conditions. In total, 51 samples have been analyzed; 92 species and intraspecific taxa are identified in 26 samples (SOM-6) and classified into four ecological groups (SOM-7). No shells were found in 25 samples; this may reflect the reworked character of the sediment (fragile shells were destroyed), or alternatively such deposits were never exposed long-term at a paleo-surface and/or inhabited by testate amoebae.

In the Arga Complex deposits Testacea are absent in most of the 10 samples analyzed from the Tur- 2 corer. Only at $-5.32 \mathrm{~m}$ b.r.l. do single finds of the soil species Schoenbornia humicola reflect pedogenesis. This sample is one of the few Tur- 2 samples that contain some pollen grains. More variable species and subspecies (16 taxa) occurred in the Tur-1 exposure where the xerophilous species Trigonopyxis arcula found in Unit E at $2.88 \mathrm{~m}$ a.r.l. indicates a temporarily dry condition of a generally boggy stage, with water depth of about $30 \mathrm{~cm}$ (Bobrov et al., 1999). Sphagnobiotic species of genera Heleopera and Nebela dominate at $4.18 \mathrm{~m}$ a.r.l. However, the hydrophilic species Phryganella hemisphaerica, and hydrophilous Centropyxis elongata and C. cassis, indicating oligo-mesotrophic boggy conditions, were also found there. Testacea (10 taxa) were found in only one sample from the Ebe- 4 exposure at $4.80 \mathrm{~m}$ a.r.l. Three species of the genus Arcella, especially the hydrophilic Arcella discoides and two hydrobiotic species of genus Difflugia, and the absence of soil eurybiotic and sphagnobiotic species reflect aquatic conditions.

At the third terrace, the Peat Unit of the Kha-2 exposure exhibits the highest Testacea abundance (up to 25 taxa). This wet and boggy habitat is evidenced by sphagnobiotic species of genus Heleopera and Nebela, hydrophilous species of genera Difflugia and Lagenodifflugia, and by hygrophilous Centropyxis aculeata, C. discoides, and C. platystoma. Decreasing numbers of hydrophilous species of genus Difflugia and the partial absence of the obligatory hydrobiotic genus Lagenodifflugia indicate alternating moisture conditions. Well-preserved shells of eurybiotic soil species and hygrophilous Difflugia lucida found at $8.7 \mathrm{~m}$ a.r.l. indicate drier soil conditions. The Testacea assemblages reflect a generally wet soil environment, with occasional dry periods. This conclusion is in good accordance with the dominance of sedge pollen in the Peat Unit.

The predominances of hygrophilous species from the sphagnobiotic group (Centropyxis aculeata, C. discoides, C. ecornis, C. gibba, Cyclopyxis arcelloides, Heleopera petricola, and H. sylvatica), and of hygro-hydrophilous species of genus Difflugia (D. lucida and D. minuta) in exposure Kha-3 also point to boggy conditions. Calceophilic C. plagiostoma, C. plagiostoma f. longa, and C. plagiostoma major were also found at this site.

The Lower Sand Unit of the Nagym section (Fig. 1C) at $0.7 \mathrm{~m}$ a.r.l. contains eurybiotic soil species of the genera Centropyxis and Cyclopyxis, pointing to an initial stage of soil formation. Eurybiotic, sphagnobiotic, and hydrobiotic soil species (5 taxa), including single shells of hygrophilous species from the genus Difflugia and the eurybiotic Centropyxis sylvatica, dominate at $7 \mathrm{~m}$ a.r.l. The absolute dominance of Trinema lineare indicates a water depth of $25-30 \mathrm{~cm}$ which is optimal for the growth of the named species (Bobrov et al., 1999), reflecting boggy conditions. Two subspecies with sizes smaller than the form typica indicate unfavorable soil conditions for testate amoebas (Bobrov and Mazey, 2004). Several sandy samples from this unit do not contain any shells, indicating poor preservation of Testacea under fluvial accumulation conditions.

In the Ice Complex Unit of the Nagym exposure, some samples containing the sphagnobiotic species Heleopera petricola and Difflugia lucida characterize boggy conditions, whereas other deposits containing hydrobiotic Difflugia penardi and D. pulex were accumulated under aquatic conditions. In addition, the domination of some deposits by eurybiotic soil species e.g. Schoenbornia humicola indicates pedogenesis. The uppermost Ice Complex sample (22.6 m a.r.l.) contains hydrophilous species of the genus Difflugia and hygrophilous Phryganella hemisphaerica, reflecting a very shallow water depth of 0-5 cm (Bobrov et al., 1999). Sphagnobiotic Heleopera petricola and Euglypha compressa f. glabra, with fragile shells that can be easily destroyed and are therefore very rarely preserved, are present in a buried surface horizon of a wet sphagnum bog. Finally, the Holocene cover deposit of the Nagym exposure radiocarbon-dated to about $4.8 \mathrm{kyr}$ BP contains the species Centropyxis ecornis v. minima and Phryganella hemisphaerica, which prefer wet habitats.

In general, soil species are most abundant in the Ice Complex Unit, together with hygrophilous and sphagnobiotic taxa (SOM-6), while Testaceae associations in the Lower Sand Unit are dominated by hydrophilic and hydrobiotic taxa.

\section{Discussion and interpretation}

Based on our studies, the Arga Complex is composed of several sand units of predominantly fluvial origin that were subsequently affected by subaerial periglacial processes such as frost cracking, eolian reworking, cryosol formation, and thermokarst. The entire sand sequence exposed in the Tur-2 core is interpreted as deposits of a late Pleistocene paleo-Lena River system, which flowed further to the northwest than the modern main Lena River channels (Fig. 11A), crossing the exposed Laptev Shelf. An extended (braided) river 
system was formed on this shelf plain when the Lena River left its narrow valley (the "Lena pipe" or "Lensky truba", Alekseev and Drouchits, 2004) between the Chekanovsky and the Kharaulakh ridges.

The combined Tur-2/Tur-1 sequence on Turakh-Sise Island represents an almost continuous period of late Pleistocene sedimentation by the Lena River when the thick sand deposits of the Arga Complex were accumulated. Changes in granulometry, MS, TOC, and mica content indicate the fluvial dynamics of river runoff, sedimentation area, and source material (e.g. flow channels, river banks, sand bars, and a shallow oxbow lake).

The oldest studied sand deposits of the Arga Complex, radiocarbondated to $>50 \mathrm{kyr} \mathrm{BP}$, consist of well-sorted weakly-bedded mediumgrained sand with the highest MS values (Unit A), corresponding to a river channel with high stream velocity during the MIS 4 period (Fig. 11A).

A decrease in runoff and a shallower water depth are probably the reason for smaller grain sizes and higher accumulation of organic remains in the segments of Units $B_{1}, C$, and $B_{2}$. This reflects conditions in an oxbow lake during the early MIS 3 (Fig. 11A). Changes in grainsize parameters were caused by seasonally or annually variable river discharge. The continuing relatively high mica and magnetic mineral contents were contributed by specific source materials, and were enriched because of lower stream velocity. Based on similar sedimentological parameters and geochronological results (Table 5), we assume that the accumulation areas of the Lower Sand Unit of the third terrace and Units A to $C$ of the Arga Complex belonged to the same river system but are from different local facies. We correlate the sand deposits exposed between 0 and $15 \mathrm{~m}$ a.r.l. along the Olenyekskaya Channel and its tributaries with sand deposits of the Arga Complex, which today are located deeper than $6 \mathrm{~m}$ b.r.l. These deposits were accumulated in a fluvial runoff system that was more than one hundred kilometers wide. Only later was the primary consistent landscape development divided into two orientations in different territories (Table 5).

The thickest and most widespread deposits of the Arga Complex are the relatively coarse-grained, well-sorted, and organic-free sands of Unit D. A periglacial river landscape with a network of continuouslyflowing river branches (Fig. 11B) is assumed from the late MIS 3 until the late MIS 2 period (40-15 kyr BP). Vandenberghe and Woo (2002) described such a multichannel periglacial runoff system as anastomosing rivers, which are characterized by individual channels in stable positions, in contrast to braided rivers whose channels migrate irregularly and can run dry.

Comparing the geochronological data of Arga Complex sand deposits on the second terrace and Ice Complex deposits on the third terrace, we have ample evidence to conclude that both deposits were partially formed during the same period (Fig. 11B). Plant

Table 5

Stratigraphical correlation of the second terrace sequences (Arga Complex) and of the third terrace sequences.

\begin{tabular}{|c|c|c|c|c|}
\hline \multirow{2}{*}{$\begin{array}{l}\text { Period } \\
\text { (kyr) }\end{array}$} & \multirow{2}{*}{$\frac{\text { 2nd terrace }}{\text { Arga Complex }}$} & \multicolumn{3}{|l|}{ 3rd terrace } \\
\hline & & Khardang-Sise & Nagym site & Kurungnakh-Sise \\
\hline $\begin{array}{c}0.7 \text { to } \\
0.3\end{array}$ & $\begin{array}{l}\text { Units } F \text { and } G \\
\text { Peat and dune }\end{array}$ & - & - & - \\
\hline $\begin{array}{c}10 \text { to } \\
3\end{array}$ & $\begin{array}{l}\text { Unit E } \\
\text { Cryosol }\end{array}$ & - & Holocene cover & $\begin{array}{l}\text { Holocene cover, } \\
\text { Alas deposits }\end{array}$ \\
\hline $\begin{array}{c}20 \text { to } \\
12\end{array}$ & $\begin{array}{l}\text { Unit D } \\
\text { Fluvial sand }\end{array}$ & - & - & - \\
\hline $\begin{array}{c}40 \text { to } \\
20\end{array}$ & $\begin{array}{l}\text { Unit D } \\
\text { Fluvial sand }\end{array}$ & Ice Complex Unit & Ice Complex Unit & $\begin{array}{l}\text { Ice Complex } \\
\text { Unit }\end{array}$ \\
\hline $\begin{array}{c}50 \text { to } \\
40\end{array}$ & $\begin{array}{l}\text { Unit } B_{1}, C, B_{2} \\
\text { Fluvial, } \\
\text { alternating }\end{array}$ & Peaty soil zone & Peaty soil & Peaty soil \\
\hline$>50$ & $\begin{array}{l}\text { Unit A } \\
\text { Fluvial }\end{array}$ & $\begin{array}{l}\text { Lower Sand Unit } \\
\text { Fluvial }\end{array}$ & $\begin{array}{l}\text { Lower Sand Unit } \\
\text { Fluvial }\end{array}$ & $\begin{array}{l}\text { Lower Sand Unit } \\
\text { Fluvial }\end{array}$ \\
\hline
\end{tabular}

macrofossil studies from the Nagym section (SOM-4) as well as from the Buor Khaya site on Kurungnakh-Sise Island (Wetterich et al., 2008) indicate no sharp vegetation shift between the Lower Sand Unit and the overlying Ice Complex Unit. During this period, paleogeographical changes were not directly driven by climate but by regional neotectonic movements in the Arctic rift zone. In addition, we must distinguish between the formation of Ice Complex deposits on EbeSise, Kurungnakh-Sise, and Khardang-Sise islands. The latter deposits are younger and finer-grained (Fig. 7A) than either of the others, and the Ice Complex deposits of Kurungnakh-Sise Island are significantly different in their heavy mineral content (Table 3). Therefore, we assume that the Ice Complexes of Ebe-Sise and Khardang-Sise islands were formed as Lena Delta floodplain sediments during the MIS 3 and MIS 2 periods, respectively. During this time, the Lena River flowed further northwest of this site. The Ice Complex deposits exposed further east along the Olenyekskaya Channel were formed by proluvial sediments from Chekanovsky Ridge which accumulated on a flat foreland plain in front of the mountain range (Fig. 11B) as already described by Schirrmeister et al. (2003), Schwamborn et al. (2002c), and Wetterich et al. (2008). Various accumulation processes (e.g. proluvial, alluvial, nival, and eolian) during different periods and in different landscapes (Schirrmeister et al., 2010) formed the polygenetic Ice Complex of the third terrace.

Later, the Ice Complex area was eroded by the Lena River as it formed large meanders $20-30 \mathrm{~km}$ in size, which are still visible today at the northern rims of Khardang-Sise, Dzhangilakh-Sise, and Kurungnakh-Sise islands (Figs. 1B and 11C). This erosive event could not be dated directly but we assume it occurred during the strong Lateglacial landscape transformation, when thermokarst processes (Romanovskii et al., 2000) and the postglacial shelf transgression (Bauch et al., 2001) started to transform the regional hydrological system of the shelf landscape. In addition, neotectonic events (Are and Reimnitz, 2000) probably affected the environmental dynamics.

The Arga Complex Unit E, characterized by the specific, thin, lattice-like arranged ice veins and weakly-developed cryosol horizons, consists of deposits similar to those of Unit D, which were later (15-12 kyr BP) affected by cryogenesis and pedogenesis. A rich assemblage of testate amoebae reflects subaerial soil formation. The relative heavy isotope signature of ice wedges in Unit $\mathrm{E}$ reflects warmer winter temperatures that are presumably characteristic of the temperate Lateglacial Bølling-Allerød Interstadial. Frost cracking and soil formation proceeded more or less synchronously during the Lateglacial to Early Holocene transition period, when the landscape was affected by further strong transformation.

Areas of the second and the third terraces were strongly affected by permafrost degradation, which caused large thermokarst depressions as well as numerous small thermokarst valleys to form. According to studies from Nikolay Lake on Arga-Muora-Sise Island, thermokarst processes started around $10 \mathrm{cal}$ kyr BP (Andreev et al., 2004; Schwamborn et al., 2002a). In general, thermokarst lake growth in Ice Complex areas in the Laptev Sea coastal lowlands must have happened very rapidly as thermokarst deposits had already appeared by $11.5 \mathrm{cal}$ yr BP (Grosse et al., 2007; Schirrmeister et al., 2002). Today, the existence of peat soils within thermokarst depressions on the Arga Complex (Ulrich et al., 2009) and on top of the studied exposures indicates surface stabilization without significant thermokarst processes.

The question remains: Why has the Arga Complex been preserved in its separate shape, and not further influenced by river and delta activities? Late Pleistocene neotectonic activities perhaps resulted in a relative uplift of the area and in a reorganization of the river system with a new westward runoff of the Lena River along the Olenyekskaya Channel (Fig. 11D). Similar and stronger tectonically-caused reorganization of the middle and lower Lena River systems was assumed by Alekseev and Drouchits (2004) for the middle Pleistocene. If this is 
true, the uplift disturbed the thermal permafrost balance and supported the ongoing thermokarst processes. Perhaps the formation of the numerous NNE-SSW-oriented lakes (Morgenstern et al., 2008) was partly caused by the existence of former river branch courses and unfrozen zones (taliks) below the river bottom.

Rather good internal data consistency exists for both the AMS and OSL dating methods (Figs. 3 and 6). However, the AMS and OSL age sequences differ significantly between each other, and OSL ages are almost always younger. Similar problems of permafrost dating using two different methods were already presented by Winterfeld et al. (under review) for permafrost sequences from the western Laptev Sea. An age difference of a factor of two is a systematic error that, thus far, cannot be explained. Potential reasons concern different physical effects for dating with correspondingly different uncertainties, as well as permafrost-specific cryogenic processes which perhaps mobilized and relocated sediment or affected mineral crystal parameters as ice grew within pore spaces. Systematic tests of factors and processes potentially impacting AMS and OSL dating methods for permafrost samples are needed.

Finally, the landscape dynamics of this region can be discussed within a larger regional context. About $90 \mathrm{kyr}$ ago the easternmost boundary of the Eurasian Ice Sheet was located in the Byrranga Mountains on the Taymyr Peninsula and in the Putorana Plateau in Central Siberia (Svendsen et al., 2004), which are about $700 \mathrm{~km}$ and $1200 \mathrm{~km}$ away from the Lena Delta study sites, respectively. Because of these large distances, a direct glacio-fluvial influence of the Eurasian Ice Sheet is very unlikely. During the Middle and Late Weichselian periods the eastern margin of the Eurasian Ice Sheet was even further west, and thus even farther away from our study region. We assume that the landscape dynamics of the Lena catchment probably exerted a very large influence on changes in the hydrological regime in our study region. The late Pleistocene glaciation of the Verkhoyansky Mountains was expressed by several strong mountain glacier advances during the early Weichselian (MIS 4) period, and minor advances during the Middle and Late Weichselian (Arkhipov et al., 1986; Kind, 1975; Kolpakov, 1979; Popp et al., 2006; Stauch and Gualtieri, 2008; Stauch and Lehmkuhl, 2010; Stauch et al., 2007). These glacier dynamics, as well as paleoprecipitation patterns in the large Lena catchment, likely also controlled the dynamics of the Lena River in its lower reaches.

\section{Conclusions}

Several stages of landscape and paleoenvironmental dynamics could be classified for the late Pleistocene and Holocene of the western Lena Delta. The Arga Complex is composed of several sand units reflecting various fluvial facies of the paleo-Lena (e.g. river channels, sand bars, and oxbow lakes); later cryogenic processes such as freezing, frost cracking, cryoturbation, and epigenetic ice wedge growth were superimposed upon it.

The MIS 4 glacial period in the Laptev Sea coastal lowland is characterized by a fluvial landscape. This is evidenced by the Lena Delta record and by similar sand deposits below the Ice Complex further west at Cape Mamontov Klyk (Schirrmeister et al., 2008; Winterfeld et al., under review) and at Bykovsky Peninsula further east (Grosse et al., 2007; Schirrmeister et al., 2002).

During the MIS 3 Interstadial the river landscape shifted further north, and the sand sequences in front of the Chekanovsky Ridge were covered by subaerial-formed ice-rich deposits (i.e. Ice Complexes) that accumulated in a polygonal landscape. Fluvial sand deposits of the Arga Complex accumulated synchronously with, and in relatively close proximity to Ice Complex deposits. The possible reasons for shifts of the Lena River hydrological regime include changes in the runoff patterns due to higher fluvial spring and summer runoff during the interstadial time, or seismotectonic events, or both together.
Both fluvial and subaerial accumulation continued during the MIS 2 glacial period. However, Ice Complex deposits from this period are not well preserved along the Olenyekskaya Channel, probably due to erosion by the reactivated western main delta channel and thermokarst processes in the subsequent Holocene period.

During the MIS 4 and 3 periods the study area was dominated by tundra steppe with locally varying environmental conditions. Changes in paleoecological records also reflect landscape dynamics, i.e. sediment accumulation patterns. A strong thermokarst-related landscape transformation during the Lateglacial and the Holocene is supported by ground ice and paleoecological records reflecting a general warming trend and the occurrence of shrub tundra during the Lateglacial to Middle Holocene and of arctic tundra during the late Holocene.

In general, shifts in the runoff system recorded in paleofluvial sediments of the Lena Delta area were caused by late Pleistocene tectonic and paleoclimatic events, which influenced the geomorphological relief and water runoff patterns and volume.

Supplementary materials related to this article can be found online at doi:10.1016/j.palaeo.2010.10.045.

\section{Acknowledgements}

This study was conducted within the framework of the RussianGerman "Laptev Sea System" scientific collaboration. The plant macrofossil studies were supported by the German Research Foundation (DFG) within the KI 849 project. We thank all Russian and German colleagues who helped us with Siberian fieldwork in 2005. The analytical work in the laboratories at the Alfred Wegener Institute Potsdam was greatly supported by Ute Bastian and Lutz Schönicke. We also thank Prof. P. Grootes and his colleagues at the Leibniz Laboratory for Radiometric Dating and Stable Isotope Research (Kiel, Germany) for their excellent radiocarbon analyses. Finally, the paper benefited by valuable comments and English language correction from Dr. Candace O'Connor (University of Alaska, Fairbanks).

\section{References}

Alekseev, M.N., Drouchits, V.A. 2004. Quaternary fluvial sediments in the Russian Arctic and Subarctic: Late Cenozoic development of the Lena River system, northeastern Siberia. Proceedings of the Geologists' Association 115 (4), 339-346.

Andreev, A.A., Tarasov, P.E., Siegert, Ch., Ebel, T., Klimanov, V.A., Melles, M., Bobrov, A.A., Dereviagin, A.Yu., Lubinski, D.J., Hubberten, H.-W., 2003. Vegetation and climate changes on the northern Taymyr, Russia during the Upper Pleistocene and Holocene reconstructed from pollen records. Boreas 32, 484-505.

Andreev, A.A., Tarasov, P.E., Schwamborn, G., Ilyashuk, B.P., Ilyashuk, E.A., Bobrov, A.A., Klimanov, V.A., Rachold, V., Hubberten, H.-W., 2004. Holocene paleoenvironmental records from Nikolay Lake, Lena River Delta, Arctic Russia. Palaeogeography, Palaeoclimatology, Palaeoecology 209, 197-217.

Are, F., Reimnitz, E., 2000. An overview of the Lena River Delta setting: geology, tectonics, geomorphology, and hydrology. Journal of Coastal Research 16 (4) 1083-1093.

Arkhipov, S.A., Isayeva, L.L., Bespaly, V.G., Glushkova, O., 1986. Glaciations of Siberia and north-east USSR. Quaternary Science Reviews 5, 463-474.

Bauch, H.A., Mueller-Lupp, T., Taldenkova, E., Spielhagen, R.F., Kassens, H., Grootes, P.M. Thiede, J., Heinemeier, J., Petryashov, V.V., 2001. Chronology of the Holocene transgression at the North Siberian margin. Global and Planetary Change 31, 125-139.

Berglund, B.E., Ralska-Jasiewiczowa, M., 1986. Pollen analysis and pollen diagrams. In: Berglund, B.E. (Ed.), Handbook of Holocene Palaeoecology and Palaeohydrology. Interscience, New York, pp. 455-484.

Bobrov, A., Mazey, Yu., 2004. Morphological variability of testate amoebae (Rhizopoda: Testacealobosea: Testaceafilosea) in natural populations. Acta Protozoologica 43 133-146.

Bobrov, A.A., Charman, D.J., Warner, B.G., 1999. Ecology of testate amoebae (Protozoa: Rhizopoda) on peatlands in Western Russia with special attention to niche separation in closely related taxa. Protist 150, 125-136.

Bobrov, A.A., Andreev, A.A., Schirrmeister, L., Siegert, C., 2004. Testate amoebae (Protozoa: Testacea) as bioindicators in the Late Quaternary deposits of the Bykovsky Peninsula, Laptev Sea, Russia. Palaeogeography, Palaeoclimatology, Palaeoecology 209, 165-181. 
Chardez, D., 1965. Ecologie generale des Thecamoebiens (Rhizopoda, Testacea). Bulletin de l'Institut Agronomigue et des Stations de Recherches Gembloux 3, 306-341.

Craig, H., 1961. Isotopic variations in meteoric waters. Science 133, 1702-1703.

Dansgaard, W., 1964. Stable isotopes in precipitation. Tellus 16, 436-468.

Drachev, S.S., Savostin, L.A., Groshev, V.G., Bruni, I.E., 1998. Structure and geology of the continental shelf of the Laptev Sea, Eastern Russian Arctic. Tectonophysics 298, 357-393.

Galabala, R.O., 1987. New data on the structure of the Lena Delta. In: Pokhialianen, V.P. (Ed.), Quaternary Period Northeast Asia. SVKNIIDVO AN SSSR, Magadan, pp. 152-171 (in Russian).

Grigoriev, N.F., 1966. Perennially Frozen Ground of the Yakutian Maritime Zone. Nauka, Moscow. 180 pp. (in Russian).

Grigoriev, M.N., 1993. Cryomorphogenesis of the Lena River Mouth Area - Yakutsk. SO AN SSSR. (in Russian), $176 \mathrm{pp}$.

Grigoriev, M.N., Rachold, V., Bolshiyanov, D.Yu., Pfeiffer, E.-M., Schirrmeister, L., Wagner, D., Hubberten, H.-W. (Eds.), 2003. Russian-German Cooperation System Laptev Sea: The Expedition LENA 2002: Reports on Polar Research, 466. 341 pp.

Grimm, E., 2004. Tilia, Tilia · Graph and TGView 2.0.2. Illinois State Museum, Springfield, USA

Grootes, P.M., Nadeau, M.-J., Rieck, A., 2004. 14C-AMS at the Leibniz-Labor: radiometric dating and isotope research. Nuclear Instruments and Methods in Physical Research Section B 223-224, 55-61.

Grosse, G., Schirrmeister, L., Siegert, Ch., Kunitsky, V.V., Slagoda, E.A., Andreev, A.A., Dereviagyn, A.Y., 2007. Geological and geomorphological evolution of a sedimentary periglacial landscape in Northeast Siberia during the Late Quaternary. Geomorphology $86(1 / 2)$, 25-51.

Grosswald, M.G., 1998. Late-Weichselian ice sheets in Arctic and Pacific Siberia. Quaternary International 45 (46), 3-18.

Gusev, A.I., 1961. Stratigraphy of Quaternary deposits of the Coastal plain. In: Lungersgauzen, G.F., Ravsky, E.I. (Eds.), Soveshchaniya po izucheniyu chetvertichnogo perioda, vol. III, pp. 119-127 (in Russian).

Hinkel, K.M., Frohn, R.C., Nelson, F.E., Eisner, W.R., Beck, R.A., 2005. Morphometric and spatial analysis of thaw lakes and drained thaw lake basins in the western arctic coastal plain, Alaska. Permafrost and Periglacial Processes 16, 327-341.

IQW, 2009. Kienast, F. [continuously updated] Index Herbariorum Website: http:// sweetgum.nybg.org/ih/herbarium.php?irn=154437. Index Herbariorum: Herbarium Senckenbergianum Weimar.

Ivanov, O.A., 1972. Stratigraphy and correlation of Neogene and Quaternary deposits in subarctic plains of East Yakutia. In: Khomentovsky, A.S., Tsetlin, S.M. (Eds.), Problems of the Quaternary Period Study. Moscow, Nauka, pp. 202-211.

Kienast, F., Schirrmeister, L., Siegert, C., Tarasov, P., 2005. Palaeobotanical evidence for warm summers in the East Siberian Arctic during the last cold stage. Quaternary Research 63, 283-300.

Kind, N.V., 1975. Glaciations in the Verkhoyansk Mountains and their place in the radiocarbon chronology of the Late Pleistocene Anthropogene. Biuletyn Peryglacjalny $24,41-54$

Kolpakov, V.V., 1979. Glacial and periglacial relief of the Verkhoyansk glacial region and new radiocarbon datings. In: Muzins, A.I. (Ed.), Regional Geomorphology of Newly Developed Areas: Geographical Society of the USSR, pp. 83-97 (in Russian).

Kolpakov, V.V., 1983. Eolian deposits during the Quaternary of Yakutia. Byulleten' Komissii Izucheniyu Chetvertichnogo Perioda 52, 123-131 (In Russian).

Krbetschek, M.R., Gonser, G., Schwamborn, G., 2002. Luminescence dating results of sediment sequences of the Lena Delta. Polarforschung 70, 83-88.

Kulig, G., 2005. Erstellung einer Auswertesoftware zur Altersbestimmung mittels Lumineszenzverfahren unter spezieller Berücksichtigung des Einflusses radioaktiver Ungleichgewichte in der 238U-Zerfallsreihe. (Programming of an analysis software for age determination using luminescence methods taking into account influences of radioactive disequilibria of the $238 \mathrm{U}$ decay series.) BSc thesis, Department of Geology, Technische Universität Bergakademie Freiberg, Germany, 35 pp.

Kunitsky, V.V., 1989. Cryolithology of the Lower Lena Region. Permafrost Institute Press, Yakutsk. 162 pp. (In Russian).

Lungersgauzen, G.F., 1961. Geological history of the middle Lena and some questions of Quaternary deposits stratigraphy in East Siberia. In: Lungersgauzen, G.F., Ravsky, E.I. (Eds.), Proceedings of the USSR Conference on Quaternary Studies, vol. 3. SAS Publishers, Moscow, pp. 209-217.

Makeyev, V.M., Ponomareva, D.P., Pitulko, V.V., Chernova, G.M., Solovyeva, D.V., 2003. Vegetation and climate of New Siberian Islands for the past 15, 000 years. Arctic, Antarctic and Alpine Research 35, 28-35.

Meyer, H., Schönicke, L., Wand, U., Hubberten, H.-W., Friedrichsen, H., 2000. Isotope studies of hydrogen and oxygen in ground ice - experiences with the equilibration technique. Isotopes in Environmental and Health Studies 36, 133-149.

Morgenstern, A., Grosse, G., Schirrmeister, L., 2008. Genetic, morphological, and statistical characterization of lakes in the permafrost-dominated Lena Delta. In: Kane, D.L., Hinkel, K.M. (Eds.), Proceedings of the 9th International Conference on Permafrost, 29 June-3 July 2008, Fairbanks, Alaska. Institute of Northern Engineering, University of Alaska Fairbanks, pp. 1239-1244.

Murray, A.S., Wintle, A.G., 2000. Luminescence dating of quartz using an improved single-aliquot regenerative-dose protocol. Radiation Measurements 32, 57-73.

Nadeau, M.J., Schleicher, M., Grootes, P.M., Erlenkeuser, H., Gottdang, A., Mous, D.J.W., Sarntheim, J.M., Willkomm, H., 1997. The Leibniz-Labor facility at the ChristianAlbrecht-University, Kiel, Germany. Nuclear Instruments and Methods in Physics Research 123, 22-30.

Nadeau, M.J., Grootes, P.M., Schleicher, M., Hasselberg, P., Rieck, A., Bitterling, M., 1998. Sample throughput and data quality at the Leibniz-Labor AMS facility. Radiocarbon 40, 239-245.
Pavlova, E.Y., Dorozhkina, M.V., 2000. The Holocene alluvial delta relief complex and hydrological regime of the Lena River Delta. Polarforschung 70, 89-100.

Pisaric, M.F.J., MacDonald, G.M., Velichko, A.A., Cwynar, L.C., 2001. The lateglacial and postglacial vegetation history of the northwestern limits of Beringia, based on pollen, stomate and tree stump evidence. Quaternary Science Reviews 20, 235-245.

Popp, S., Diekmann, B. Meyer, H., Siegert, C. Syromyatnikov, I., Hubberten, H.-W., 2006. Palaeoclimate signals as inferred from stable-isotope composition of ground ice in the Verkhoyansk Foreland, Central Yakutia. Permafrost and Periglacial Processes $17,119-132$.

Rachold, V., Grigoriev, M.N. (Eds.), 1999. Russian-German Cooperation SYSTEM LAPTEV SEA 2000: The Lena Delta 1998 Expedition: Reports on Polar Research, 315, pp. $1-262$.

Rachold, V., Grigoriev, M.N. (Eds.), 2000. Russian-German Cooperation SYSTEM LAPTEV SEA 2000: The Expedition Lena Delta 1999: Report on Polar Research, 354, pp. 1-269.

Rachold, V., Grigoriev, M.N. (Eds.), 2001. Russian-German Cooperation SYSTEM LAPTEV SEA 2000: The Lena Delta 2000 Expedition: Reports on Polar Research, 388. $136 \mathrm{pp}$.

Romanovskii, N.N., Hubberten, H.-W., Gavrilov, A.V., Tumskoy, V.E., Tipenko, G.S Grigoriev, M.N. Siegert, Ch. 2000. Thermokarst and land-ocean interactions, Laptev Sea Region, Russia. Permafrost and Periglacial Processes 11, 137-152.

Saks, V.N., Strelkov, S.A., 1960. Mesozoic and Cenozoic of the Soviet Arctic. In: Raasch, G.O. (Ed.), Geology of the Arctic. Proceedings of the First International Symposium on Arctic Geology held in Calgary, Alberta, January 11-13,1960, under the Auspices of the Alberta Society of Petroleum Geologists, Vol. I. University of Toronto Press, Toronto, pp. 48-67.

Schirrmeister, L., Siegert, C., Kunitsky, V.V., Grootes, P.M., Erlenkeuser, H., 2002. Late Quaternary ice-rich permafrost sequences as a paleoenvironmental archive for the Laptev Sea Region in northern Siberia. International Journal of Earth Sciences 91, 154-167.

Schirrmeister, L., Kunitsky, V.V., Grosse, G., Schwamborn, G., Andreev, A.A., Meyer, H., Kuznetsova, T., Bobrov, A., Oezen, D., 2003. Late Quaternary history of the accumulation plain north of the Chekanovsky Ridge (Lena Delta, Russia) - a multidisciplinary approach. Polar Geography 27, 277-319.

Schirrmeister, L., Wagner, D., Grigoriev, M.N., Bolshiyanov, D.Y., 2007. The Expedition LENA 2005. In: Schirrmeister, L. (Ed.), Expeditions in Siberia in 2005: Reports on Polar and Marine Research, 550, pp. 41-242.

Schirrmeister, L., Grosse, G., Kunitsky, V., Magens, D., Meyer, H., Dereviagin, A., Kuznetsova, T., Andreev, A Babiy, O, Kienast, F, Grigoriev, M Overduin, P.P. Preusser, F., 2008. Periglacial landscape evolution and environmental changes of Arctic lowland areas for the last 60, 000 years (Western Laptev Sea coast, Cape Mamontov Klyk). Polar Research 27, 249-272.

Schirrmeister, L., Kunitsky, V.V., Grosse, G., Wetterich, S., Meyer, H., Schwamborn, G., Babiy, O., Derevyagin, A.Y., Siegert, C., 2010. Sedimentary characteristics and origin of the Late Pleistocene Ice Complex on North-East Siberian Arctic coastal lowlands and islands - a review. Quaternary International. doi:10.1016/j.quaint.2010.04.004

Schirrmeister, L., Grosse, G., Kunitsky, V.V., Fuchs, M.C., Krbetschek, M., Andreev, A.A Herzschuh, U., Babyi, O., Siegert, C., Meyer, H., Derevyagin, A.Y., Wetterich, S., 2009. The mystery of Bunge Land (New Siberian Archipelago): Implications for its formation based on palaeoenvironmental records, geomorphology, and remote sensing. Quaternary Science Reviews 29, 3598-3616.

Schwamborn, G., Schneider, W., Grigoriev, M.N., Rachold, V., Antonow, M., 1999. Sedimentation and environmental history of the Lena Delta. In: Rachold, V. Grigoryev, M.N. (Eds.), Russian German Cooperation SYSTEM LAPTEV SEA 2000 The Lena Delta 1998 Expedition: Reports on Polar Research, 315, pp. 94-111.

Schwamborn, G., Andreev, A.A., Rachold, V., Hubberten, H.-W., Grigoriev, M.N., Tumskoy, V., Pavlova, E.Y., Dorozhkina, M.V., 2002a. Evolution of Lake Nikolay, Arga Island, Western Lena River delta, during Late Pleistocene and Holocene time. Polarforschung 70, 69-82.

Schwamborn, G., Dix, J.K., Bull, J.M., Rachold, V., 2002b. High-resolution seismic and ground penetrating radar - geophysical profiling of a thermokarst lake in the western Lena Delta, Northern Siberia. Permafrost and Periglacial Processes 13, 259-269.

Schwamborn, G., Rachold, V., Grigoriev, M.N., 2002c. Late Quaternary sedimentation history of the Lena Delta. Quaternary International 89, 119-134.

Stauch, G., Gualtieri, L.M., 2008. Late Quaternary glaciations in northeastern Russia. Journal of Quaternary Science 23, 545-558.

Stauch, G., Lehmkuhl, F., 2010. Quaternary glaciations in the Verkhoyansk Mountains, Northeast Siberia. Quaternary Research 74, 145-155.

Stauch, G., Lehmkuhl, F., Frechen, M., 2007. Luminescence chronology from the Verkhoyansk Mountains (North-Eastern Siberia). Quaternary Geochronology 2 , 255-259.

Stuiver, M., Reimer, P.J., Bard, E., Beck, J.W., Burr, G.S., Hughen, K.A., Kromer, B., McCormac, G., van der Plicht, J., Spurk, M., 1998. INTCAL98 radiocarbon age calibration, 24, 000-0 cal BP. Radiocarbon 40, 1041-1083.

Svendsen, J.I., Alexanderson, H., Astakhov, V.I., Demidov, I., Dowdeswell, J.A., Funder, S. Gataullin, V., Henriksen, M., Hjort, C., Houmark-Nielsen, M., Hubberten, H.-W. Ingolfsson, O., Jacobsson, M., Kjær, K., Larsen, E., Lokrantz, H., Lunkka, J.P., Lysa, A., Mangerud, J., Matioushkov, A., Murray, A., Moeller, P., Niessen, F., Nikolskaya, O. Polyak, L., Saarnisto, M., Siegert, C., Siegert, M.J., Spielhagen, R.F., Stein, R., 2004. Late Quaternary ice sheet history of northern Eurasia. Quaternary Science Reviews 23 1229-1272.

Ulrich, M., Grosse, G., Chabrillat, S., Schirrmeister, L., 2009. Spectral characterization of periglacial surfaces and geomorphological units in the Arctic Lena Delta using field spectrometry and remote sensing. Remote Sensing of Environment 113, 1220-1235. 
Vandenberghe, J., Woo, M.K., 2002. Modern and ancient periglacial river types. Progress in Physical Geography 26, 479-506.

Walker, H.J., 1998. Arctic deltas. Journal of Coastal Research 14, 718-738.

Wetterich, S., Kuzmina, S., Andreev, A.A., Kienast, F., Meyer, H., Schirrmeister, L. Kuznetsova, T., Sierralta, M., 2008. Palaeoenvironmental dynamics inferred from late Quaternary permafrost deposits on Kurungnakh Island, Lena Delta, Northeast Siberia, Russia. Quaternary Science Reviews 27, 1523-1540.

Winterfeld, M., Schirrmeister, L., Grigoriev, M., Kunitsky, V. V., Andreev, A., Overduin, P.P., (under review). Permafrost and landscape dynamics during the Late Pleistocene, Western Laptev Sea Shelf, Siberia. Boreas. 